\title{
Anonimato historiográfico: a trajetória de Paschoal Artese na construção da modernidade urbano-arquitetônica rio-pardense
}

Historiographic anonymity: Paschoal Artese's trajectory in the construction of Rio-Pardense urban-architectural modernity

https://doi.org/10.1590/1982-02672020v28e38

\author{
NATALIA CAPPELLARI DE REZENDE' \\ hitps:// orcid.org/0000-0003-4976-8718 \\ Universidade de São Paulo / São Carlos, SP, Brasil
}

\section{MARIA ANGELA PEREIRA DE CASTRO E SILVA BORTOLUCCI²}

https://orcid.org/0000-0002-8237-1862

Universidade de São Paulo / São Carlos, SP, Brasil

RESUMO: $\bigcirc$ artigo trata do anonimato historiográfico de profissionais não diplomados que atuaram no interior do estado de São Paulo entre fins do século XIX e início do século XX, tomando como objeto de discussão a produção da moradia urbana de São José do Rio Pardo. $\bigcirc$ texto revela o envolvimento de pedreiros, serventes, marceneiros, carpinteiros, pintores, construtores e empreiteiros na construção de uma modernidade urbano-arquitetônica local, com destaque para a notável atuação do profissional sem diploma Paschoal Artese, imigrante italiano e figura-chave nesse processo. A revisão bibliográfica se fundamenta em autores como Debenedetti e Salmoni, Pareto Júnior e Francisco, cotejando as análises com base em dados obtidos de fontes primárias e pesquisa in loco. $\bigcirc$ objetivo é contribuir para a construção da historiografia da arquitetura e do urbanismo, ao ampliar o conhecimento sobre profissionais não diplomados que atuaram na produção arquitetônica rio-pardense.

PALAVRAS-CHAVE: Profissionais não diplomados da construção civil. Construção da

\begin{abstract}
1. Doutoranda do Programa de Pós-Graduação em Arquitetura e Urbanismo do Instituto de Arquitetura e Urbanismo da Universidade de São Paulo (IAU/USP), com bolsa Fapesp (Processo $^{\circ}$ 2019/26031-6). Mestre pelo IAU/USP e arquiteta e urbanista pela Pontifícia Universidade Católica de Minas Gerais (PUC Minas). Integra o grupo de pesquisa "Patrimônio, Cidades e Territórios". E-mail: <nataliacrezende@yahoo.com.br> / $<$ nataliacrezende@usp.br>.

2. Professora sênior do Instituto de Arquitetura e Urbanismo da Universidade de São Paulo (IAU/USP). Participa do Programa de Pós-Graduação em Arquitetura e Urbanismo (IAU/ USP) como docente e orientadora de mestrado e doutorado. Líder do grupo de pesquisa "Patrimônio, Cidades e Territórios" (cadastro no CNPq). E-mail: <mariacsb@sc.usp.br>.
\end{abstract}


modernidade urbano-arquitetônica no interior de São Paulo. Moradia urbana paulista. Cidade de São José do Rio Pardo (SP). Trajetória de Paschoal Artese.

ABSTRACT: The article deals with the historiographical anonymity of non-graduated professionals who worked in the interior of the state of São Paulo between the end of the 19th century and the beginning of the 20th century and takes as an object of discussion the production of urban dwelling in São José do Rio Pardo. It reveals the involvement of bricklayers, employees, woodworkers, carpenters, painters, builders and contractors in the construction of a local urban-architectural modernity, with an emphasis on the excellent performance of the professional without a diploma Paschoal Artese, Italian immigrant and key figure in this process. It bases the bibliographic review on authors pertinent to the theme, among them Debenedetti and Salmoni, Pareto Junior and Francisco, comparing the analyzes based on data obtained from primary sources and on-site research. In this way, it contributes to the construction of the historiography of architecture and urbanism, by expanding the knowledge of non-graduated professionals who worked in Rio-Pardense architectural production.

KEYWORDS: Non-graduated professionals in civil construction. Construction of urbanarchitectural modernity in the interior of São Paulo. Urban dwelling. City of São José do Rio Pardo-SP. Paschoal Artese's trajectory. 
Tínhamos cerca de 15 anos quando aqui chegamos. Viéramos sozinhos, disposto a lutar e vencer, animado que nos sentíamos por espírito jovem e combativo. [...] encaminhamos nossos esforços para a senda do progresso e bem estar público. Passamos a trabalhar incansavelmente para o desenvolvimento da cidade. ${ }^{3}$

Luta, progresso e bem-estar público: ${ }^{4}$ foram essas as palavras proferidas por um sujeito em discurso na Câmara Municipal no dia 30 de dezembro de 1966, ocasião em que, além de recusar a homenagem de outorga do título de cidadão riopardense, denunciou a mediocridade da elite local. Suas palavras, significativas, põem em evidência os conflitos materiais e simbólicos da trajetória de um profissional imigrante italiano, não diplomado, que se tornou uma figura-chave na construção da modernidade urbano-arquitetônica da cidade de São José do Rio Pardo na Primeira República. Paschoal Artese é o nome desse italiano de história confluente à de tantos outros que atuaram na construção civil e contribuíram diretamente para a produção da cidade e da cultura material, mas ainda sem o devido (re)conhecimento da historiografia.

Foi através do estudo das moradias e da cidade para contar uma versão da história de São José do Rio Pardo do final do século XIX até o final da década de 1910 que constatamos a atuação de Artese e de mais de uma centena de pessoas, entre elas artífices ${ }^{5}$ e práticos licenciados, ${ }^{6}$ que estiveram envolvidas com a produção edilícia e, consequentemente, com o próprio desenvolvimento urbano. ${ }^{7}$ Foram essas pessoas, mantidas em anonimato e desconhecidas da historiografia, as responsáveis por difundir padrões técnicos e estéticos a partir de referenciais trazidos de fora, mesclados a experiências anteriores e particularidades locais. Redimensionar esses personagens através da análise de suas trajetórias permite escapar de interpretações redutoras e permeadas de clichês, contribuindo para superar limites ainda não satisfatoriamente ultrapassados pela historiografia da arquitetura brasileira. Nesse sentido, este trabalho se alinha àqueles que na última década se voltaram ao estudo não somente da arquitetura e da moradia, mas também da cidade e dos profissionais não diplomados da construção civil.

Para a grande maioria dos pesquisadores que se dedicaram a estudar a arquitetura brasileira do final do século XIX e início do século $X X^{8}$, é inegável a presença de não diplomados, sobretudo imigrantes, em todas as etapas da construção civil. Essa presença é atestada, como afirma Lindener Pareto Júnior, ${ }^{9}$ na fala de pessoas leigas ao serem interpeladas sobre a construção urbana e arquitetônica da cidade de São Paulo entre os anos de 1893 e 1933. No entanto,
4. Este artigo é uma versão reduzida e revisada de parte do Capítulo 2 da dissertação de mestrado intitulada $A$ cidade de São José do Rio Pardo e as moradias do Centro Histórico (18651940), defendida em fevereiro de 2019 no Programa de Pós-Graduação em Arquitetura e Urbanismo do Instituto de Arquitetura e Urbanismo da Universidade de São Paulo (IAU/USP), sob a orientação da Profa. Dra. Maria Angela Pereira de Castro e Silva Bortolucci e com bolsa do CNPq (Processo $\mathrm{n}^{\circ}$ 153114/2016-9).

5. A definição apresentada no Diccionario da língua portugueza (SILVA, 1877, p. 194) para a palavra "artífice" é "artista, official de um, ou outro sexo, que sabe, ou professa alguma arte, que faz alguma cousa com artificio, estudo. Autor, inventor, machinador, ou o que traça, dispõe e executa alguma cousa".

6. De acordo com Pareto Júnior (2011, p. 18), o termo "prático licenciado" se refere a "construtores sem ensino superior habilitados pelo poder público, e reconhecidos como competentes para a prática da arquitetura". Sobre a historicidade do termo, cf. Pareto Júnior (2011, 2016).

7. Cf. Rezende (2019).

8. Cf. Lemos (1989), Reis Filho (2011), Segawa (2014) e Fabris (1987).

9. Cf. Pareto Júnior (2011).

10. Cf. Pareto Júnior (2011), e podemos citar também o trabalho de Debenedetti e Salmoni (1981).

11. Cf. Francisco (2013). 
13. Estudos que apontaram a diversidade de profissionais da construção civil e a formação do campo da engenharia e arquitetura a partir do último quartel do século XIX no Brasil, sobretudo em São Paulo, ganharam espaço na historiografia a partir da década de 1980, com trabalhos de Debenedetti e Salmoni, Carlos Lemos, Nestor Goulart Reis Filho, Sylvia Ficher e Maria Angela Bortolucci. A partir desse momento, $\mathrm{O}$ interesse por esse campo de estudo se ampliou no sentido de uma revisão da invisibilidade de personagens da construção civil, culminando no início dos anos 2010 com pesquisas que de fato apontaram trajetórias ou biografias detalhadas de profissionais sem diploma (PARETO JÚNIOR, 2011, 2016; FRANCISCO, 2013). Esses trabalhos aos poucos vão sendo tomados como referência por romper o elitismo historiográfico, esmiuçando as disputas e conflitos pelo controle de mercado de trabalho e regulamentação da profissão.

\section{Puppi (1998, p. 176).}

15. Para Camargo (2014) e Puppi (1998), foi a irremediável presença dos modernos na história da arquitetura brasileira a razão do juízo estético negativo sobre o ecletismo, como é possível acompanhar em Goodwin e Smith (1943), Costa (1936, 1962, 1995), Artigas (1986) e Bruand (1981).

16. Os nomes quase sempre escritos com erros de grafia foram conferidos com as listas de registro de imigrantes italianos que se encontram no Centro Cultural Ítalo-Brasileiro.

17. Contudo, é necessário enfatizar que, apesar dessa dominância, havia um hibridismo cultural e do "sa- apesar da legitimidade da presença de profissionais não diplomados na arquitetura urbana de cidades como São Paulo, evidenciada por Pareto Júnior, ${ }^{10}$ e Campinas, por Rita de Cássia Francisco," " a artista plástica Ivoty Macambira, em seus trabalhos sobre artesãos e produções ornamentais em gesso e estuque aplicado em fachadas da cidade de São Paulo entre 1870 e 1960, destaca que, invariavelmente, o que se reconhece é o "trabalho braçal do imigrante em geral e as habilidades do italiano em particular". ${ }^{12}$ Evidentemente, a falta de aprofundamento por parte da historiografia ${ }^{13}$ sobre esse tema pode ser justificada pelo interesse nos estudos do campo da arquitetura e do urbanismo das grandes obras e seus redutos corporativistas, destacando a trajetória profissional daqueles que foram legitimados pela classe dominante e pela tríade Estado, universidade e diploma.

Outro fator relevante é o preconceito infundado acerca das intenções plásticas predominantes no período de maior atuação dos imigrantes, sobretudo quando se trata do ecletismo. Desqualificado de antemão e taxado como sem valor estético, arquitetônico e historiográfico, o ecletismo foi rotulado de arquitetura estrangeira, em contraposição ao desejo de consolidar uma "cultura 'autêntica', nacional e com base apenas na tradição e no modernismo". ${ }^{14}$ Assim, o ecletismo foi duramente desprestigiado por resultar de uma arquitetura que, além de boa parte dos envolvidos ser de origem estrangeira, criava-se e reproduzia-se com base em referências de fora (periódicos, manuais, enciclopédias, catálogos construtivos, modelos e guias de estilos), utilizando materiais importados e a partir do interesse dos clientes. ${ }^{15}$

Nesse período, São José do Rio Pardo, cidade do interior paulista que teve o café como principal produto de sua economia, assistiu à chegada e posterior domínio da construção civil por personagens imigrados da Europa, ${ }^{16}$ principalmente italianos, ou filhos destes nascidos em terras brasileiras. Tal constatação foi feita após discriminarmos todos os nomes - o que inclui diplomados e não diplomados - encontrados em livros de impostos, jornais, almanaques e na produção historiográfica de autores locais ${ }^{17}$ (Tabela 1). Foram identificadas 27 pessoas que desempenharam a atividade de pedreiro, 16 a de servente, 11 a de marceneiro, 18 a de carpinteiro, quatro a de pintor, 12 a de construtor e empreiteiro, duas a de arquiteto (apesar de não possuírem o diploma), dentre eles Paschoal Artese, e outras quatro a de engenheiro civil. Embora esses últimos possuíssem o diploma, dedicaram-se majoritariamente a trabalhos de agrimensura e ocuparam cargos na prefeitura, enquanto inúmeros profissionais sem titulação acadêmica efetivamente estiveram envolvidos com a atividade edilícia. 
Mão de obra atuante em São José do Rio Pardo em fim do século XIX e início do século XX

\begin{tabular}{|c|c|c|}
\hline & Final do século XIX & Início do século XX \\
\hline Pedreiro & $\begin{array}{l}\text { João Delucca, Francisco de } \\
\text { Tal, Joaquim Rodrigues Car- } \\
\text { reira, Victorino da Rocha Car- } \\
\text { reira, Martiniano de Tal, Joa- } \\
\text { quim (conhecido por Guita), } \\
\text { Benedicto, Nicolas Delucca, } \\
\text { Antonio Craceia, José Giglio, } \\
\text { Raphael Picelrielo, Francisco } \\
\text { Leonardo, José de Souza, José } \\
\text { Quercia, José Gomes da Silva, } \\
\text { Manoel Rolani, Felicio Semio- } \\
\text { ne e Francisco Riga. }\end{array}$ & $\begin{array}{l}\text { Miguel Precioso, Carlos Piquet- } \\
\text { ti, Sperandio Foiadelli, Angelo } \\
\text { Acquaroli, Giacomo Marzoc- } \\
\text { chi, Abramo Savoldi, Vicente } \\
\text { Sistito, Salvador Gulli e Francis- } \\
\text { co Maida. }\end{array}$ \\
\hline Servente & & $\begin{array}{l}\text { Domingos Zamtebasso, Baptista } \\
\text { Bassini, Sebastião de Oliveira, } \\
\text { Francisco C. Martins, José Eugê- } \\
\text { nio, Eugênio Tresentino, Alberto } \\
\text { Isberti, José Galdino, Domingos } \\
\text { Honorio, Levindo de Mello, An- } \\
\text { tonio Siverino, José Ortega, Pe- } \\
\text { dro Januário, Antônio de Mello, } \\
\text { Luiz Bonet e Jonas Nani. }\end{array}$ \\
\hline Marceneiro & $\begin{array}{l}\text { Paschoal Cerávolo, Domingos } \\
\text { Cerávolo, Miguel Cerávolo, } \\
\text { Luís Rich, José Vano e Paschoal } \\
\text { Artese. }\end{array}$ & $\begin{array}{l}\text { Osorio Soares, Paschoal Ce- } \\
\text { rávolo, Domingos Cerávolo, } \\
\text { Miguel Cerávolo, Alfredo Ma- } \\
\text { riani, Fortunato Paglia, José } \\
\text { Lacorazza, Paschoal Artese e } \\
\text { Salvador Artese. }\end{array}$ \\
\hline Carpinteiro & $\begin{array}{l}\text { João Batista Blandim, José Fran- } \\
\text { cilino, José Barbosa, Hercula- } \\
\text { no de Tal, Francisco Ribeiro, } \\
\text { Antonio José dos Santos Junior, } \\
\text { Mizael Costa e Silva, Antonio } \\
\text { Cardozo dos Santos, Jacintho } \\
\text { José de Oliveira, Manoel Sera- } \\
\text { fim dos Anjos, Zeferino Gomes } \\
\text { de Avelino, Herculano Alves } \\
\text { de Moura, Joaquim Antonio da } \\
\text { Silva, Manoel Marques e José } \\
\text { Candido Lourenço. }\end{array}$ & $\begin{array}{l}\text { Osorio Soares, Angelo Colli e } \\
\text { Salvador Artese. }\end{array}$ \\
\hline Pintor & $\begin{array}{l}\text { Antônio Joaquim Teixeira, An- } \\
\text { tonio Zeferino Gonçalves e } \\
\text { Eduardo Giudice. }\end{array}$ & $\begin{array}{l}\text { Eduardo Giudice e Rodolpho } \\
\text { Giudice }\end{array}$ \\
\hline
\end{tabular}

ber fazer" entre os que chegavam e os que já estavam na cidade, constituindo um processo inacabado que em termos materiais resultou na alteração significativa da paisagem. 
18. Cf. Del Guerra (1999, 2001, 2002).

19. Cf. Macambira (1985).

20. Cf. Pareto Júnior (2011, 2016).

21. Cf. Francisco (2013)

22. O dicionário desenvolvido por Antonio de Moraes Silva se tornou modelo conhecido e apelidado como o "Morais". Sua primeira edição, publicada em 1789, teve como base o Vocabulário Portuguez e Latino de Rafael Bluteau, de 1712. Foi considerado a mais importante referência da lexicografia portuguesa ao longo dos séculos XIX e XX (cf. Verdelho, 2003).

\begin{tabular}{|l|l|l|}
\hline & Final do século XIX & Início do século XX \\
\hline Construtor / Empreiteiro & $\begin{array}{l}\text { Felicio Semione, Francisco Ri- } \\
\text { ga, Felício Calvite, Luigi Pre- } \\
\text { zzia, Giovanni Delucca, Giuse- } \\
\text { ppe Quercia e Nicola Delucca. }\end{array}$ & $\begin{array}{l}\text { Femione, Dr. Jesuíno Fe- } \\
\text { licíssimo, Rogério de Andrade, } \\
\text { Calvite e Paschoal Artese. }\end{array}$ \\
\hline Engenheiro civil & João Thimóteo Pereira da Rosa. & $\begin{array}{l}\text { Dr. Hugo Moschini, João Thi- } \\
\text { móteo Pereira da Rosa, Aristi- } \\
\text { des Dias Pinheiro e José Barbo- } \\
\text { sa de Oliveira. }\end{array}$ \\
\hline Arquiteto & $\begin{array}{l}\text { Salvador Artese, Paschoal Ar- } \\
\text { tese }\end{array}$ \\
\hline
\end{tabular}

Tabela 1 - Sistematização dos artífices e profissionais atuantes na construção civil de São José do Rio Pardo no final do século XIX e na década de 1910. Fonte: elaborado por Natalia C. Rezende com base no jornal $\bigcirc$ Rio Pardo, Livro de Imposto de Indústrias e Profissões e Del Guerra. ${ }^{18}$

Tão importante quanto essa lista nominativa de personagens da construção civil rio-pardense é o questionamento que essas informações, e outras inexistentes, podem suscitar. Por exemplo, qual a razão do registro de atuação do mesmo indivíduo no mesmo período em diversas categorias? E o que justifica a ausência de referências a serventes no final do século XIX? Talvez essas questões sejam mais bem compreendidas à luz do que já foi levantado por Macambira ${ }^{19}$ e Pareto Júnior ${ }^{20}$ sobre as imprecisões das atribuições entre categorias profissionais da construção civil, incluindo certa indistinção entre o projetar e o construir. Certamente, a ausência de clareza também estava diretamente ligada à penúria de mão de obra especializada, que, no limite, gerava uma relação de proximidade de funções, conforme também apontou Francisco. ${ }^{21}$ Ajudam a elucidar as dificuldades de definição desse quadro de profissionais as acepções dos termos consultados no "Diccionario da língua portugueza" de Antonio de Moraes Silva, ${ }^{22}$ na edição publicada em 1877 e 1878 :

- "Pedreiro, s.m. Official, que trabalha em obras de pedra, e cal, em obras de alvenaria, ou cantaria.";

- "Servente, s. m. O que ajuda em trabalho, e dá as achegas aos pedreiros, etc.";

- "Marceneiro, s.m. Official de marceneria, que lavra madeira para móveis, com mais artificio que o carpinteiro; por ex. molduras entalhadas, etc.";

- "Carpenteiro, ou Carpintèiro, s. m. Homem, que por officio trabalha em madeiras de construcção civil";

- "Pintor, s. m. O que sabe, ou exerce a pintura"; 
- "Constructor, s.m. O que faz, traça e executa".;

- "Empreiteiro, s. m. O que emprehende, e se obriga a fazer alguma obra por certa somma, v. g. um palácio, um cáes, etc.";

- "Engenheiro, s.m. $\bigcirc$ que se aplica à engenharia.";

- "Architecto, (ou Arquitecto) s. m. O que sabe e pratica a architectura edificando".

Todos esses termos e definições que designavam os profissionais da construção 23 de forma mais ou menos direta se aproximam em significado, estabelecendo uma imbricada relação entre o ato de projetar e construir. Tomando as categorias "arquiteto", "construtor" e "empreiteiro", com as quais Paschoal Artese foi identificado, percebemos com mais clareza as ilações semânticas, ou seja, o arquiteto é aquele que tem conhecimento para projetar e construir, o construtor para traçar e executar, e o empreiteiro para realizar uma obra por um preço convencionado. As atribuições se sobrepõem: um construtor pode ser um arquiteto, que por sua vez pode ser um empreiteiro. Tal situação se alarga para os registros documentais, a exemplo do Almanach Administrativo, Commercial e Industrial da Província de São Paulo de 1884, que dividia os profissionais da construção civil atuantes na cidade de São Paulo em apenas três categorias: "Empreiteiros de Obras", "Architectos" e "Engenheiros civis, mechanicos e agrimensores". ${ }^{24}$ Esse método de discriminação, além de categorizar os profissionais de maneira genérica em poucas categorias, deu preferência àqueles que tinham formação erudita, status que thes garantia visibilidade e pagavam impostos, em contraposição à exclusão de outros, considerados pouco significativos a ponto de não aparecerem nesses documentos e em estatísticas da época, a exemplo dos serventes. Nesse caso, outra hipótese para a ausência de registro dessa mão de obra em São José do Rio Pardo no final do século XIX é que, apesar de fundamentais na execução das obras, esses trabalhadores estariam subordinados a outros profissionais, sob formas precárias de contratação, de modo a permitir rápidas trocas sem prejuízos significativos para a realização do serviço.

A imprecisão dos termos mostra a dificuldade de definir as atribuições profissionais, a qual era reforçada na prática, uma vez que o limiar do campo de atuação era bastante tênue, devido à pouca disponibilidade de mão de obra especializada e diplomada. Essa situação é confirmada quando se verifica o elevado número de pedreiros, construtores e empreiteiros em comparação com o número de engenheiros durante todo o final do século XIX e início do XX, fortalecendo ainda mais a constatação de que a cidade e a arquitetura urbana de São José do Rio Pardo foram em grande parte obra de profissionais sem diploma.
23. Sobre as hibridizações e ressignificações ocorridas nesses termos no século XX, cf. Pareto Júnior (2011). 24. Cf. Pareto Júnior (2011). 
25. Adotamos a leitura em microescala, conforme aponta Lepetit (2001), ao expor a importância da sua definição na análise do objeto e da problemática. Para isso, Lepetit (2001) destaca a relevância do movimento de proximidade e de afastamento do objeto e exemplifica através de um jardim que, a depender da escala de observação, é "uma cidade, uma campina, de longe são uma cidade e uma campina; mas, à medida que nos aproximamos, são casa, árvores, telhas, folhas, grama, formigas, pernas de formigas, ao infinito. Tudo isso se reveste com o nome de campo" (PASCAL apud LEPETIT, 2001, p. 226).

26. Importante baliza para o desenvolvimento deste tipo de análise são os trabalhos de Solange Ferraz de Lima (2001, 2008) e Roberto Pastana Teixeira Lima (2001).

27. Artese (1966, p. 9).

28. Artese, loc. cit.

29. Um de seus filhos é José Germinal Artese, que nasceu em 1903, na cidade de Mococa, para onde sua família, fugindo da febre amarela em São José do Rio Pardo, se mudou por alguns meses. Germinal seguiu para São Paulo no final da década de 1910 para estudar no Liceu de Artes e Ofícios, e depois foi para o Rio de Janeiro, onde também cursou as escolas Liceu de Artes e Ofícios e Belas Artes, se formando em desenho, pintura e ornato. Entre os seus professores, destacam-se Antonio Rocco, Modesto Brocos, José Barchitta, Campos Ayres, Nicola Rollo, Henrique Vio, Rodolfo Amoedo e Rodolfo Chambelland. Entre seus colegas da escola de Belas Artes, destaca-se Candido Portinari. Germinal Artese retornou a São José do Rio Pardo no início da década de 1930 para lecionar dese-
À vista disso, aprofundamos a leitura ${ }^{25}$ e análise da produção urbanoarquitetônica, especialmente da moradia rio-pardense, dando destaque a uma fachada caracterizada pela inserção do ornato ${ }^{26}$ e a um jardim, ambos idealizados e construídos pelo imigrante italiano Paschoal Artese, figura-chave da construção civil local, além de agitador político e promotor de lutas ideológicas. A escolha dos objetos em análise, representativos da notável ałuação desse profissional não diplomado, deve-se à sua contribuição para a construção da modernidade urbanoarquitetônica rio-pardense na passagem do século XIX para o século XX. Essas escolhas também permitiram descobrir, além de Artese, inúmeros profissionais anônimos que estiveram até há pouco tempo no limbo da história local e da historiografia da arquitetura e do urbanismo brasileiro. Nesse sentido, é no quadro geral do debate historiográfico sobre trajetórias de profissionais não diplomados, que teve à frente Lindener Pareto Júnior e Rita de Cássia Francisco, que Paschoal Artese se insere. E é diante desse desafio de compreensão e aproximação dos objetos de análise que destacamos algumas das questões que nos inquietam: por que Paschoal Artese, profissional da construção civil, foi ignorado em vida? E a posteriori, por que ele não figura na historiografia da arquitetura e do urbanismo? Para isso, vamos apontar nuances e deslindar conflitos materiais e simbólicos que permearam a vida desse profissional não diplomado.

\section{PASCHOAL ARTESE, APAGAMENTO E ESQUECIMENTO INTENCIONAL}

Antes de agradecer as homenagens que neste momento nos são prestadas, queremos contar-thes, resumidamente, nossa história decorrida nesta cidade. História bem mais amarga do que doce, como a de todo homem norteado por ideais sadios e inimigo de injustiças. ${ }^{27}$

O discurso proferido por Paschoal Artese na Câmara Municipal de São José do Rio Pardo em dezembro de 1966, pouco antes de sua morte em abril de 1969, é absolutamente crucial para alcançar as razões que o levaram a ser alvo de declarada e ostensiva aversão local. Como o próprio Artese disse, sua "história [foi] bem mais amarga do que doce". ${ }^{28}$ Nascido em 26 de dezembro de 1881 em Vibo Valentia, na região da Calábria, ainda muito jovem Paschoal veio para o Brasil com seus pais, José Artese e Filomena Montesanti Artese. O italiano chegou a São José do Rio Pardo em 1897, onde se casou em primeiras núpcias com Adele Ramacciotti, com quem teve dois filhos, ${ }^{29} \mathrm{e}$ em segundas núpcias com Noemia Piovesan, com quem teve outros 12 filhos. ${ }^{30}$ Essa amargura a que se refere deve-se ao fato de ter 
encontrado nessa cidade "o ambiente dos coronéis mandões, perigosos, temíveis por seu séquito de capangas fiéis, boçais e sanguinários", 31 que the causou inúmeros conflitos materiais e simbólicos durante toda a vida, em virtude de sua defesa aguerrida dos ideais socialistas, inclusive tomando a frente da militância na cidade.

De imediato, Artese, que trouxe na bagagem a experiência de marceneiro e entalhador, 32 foi amparado por conterrâneos já bem instalados, sobretudo Paschoal Cerávolo, que the ofereceu emprego em sua marcenaria para se dedicar a serviços de carpintaria e execução de mobília, ao mesmo tempo em que reproduzia fotografias em desenho. Em 1900, vislumbrando oportunidades na construção civil, Artese abriu a sua primeira escola de desenho ornamental e geométrico, incluindo a alfabetização do operariado de forma gratuita, ${ }^{33}$ como pode ser observado na Figura 1, em que posa juntamente com seus alunos. Sem dúvida, seu objetivo era o de instruir o pobre e formar mão de obra qualificada que ele próprio utilizaria na condição de empreiteiro e construtor, obtendo dessa maneira maior qualidade em suas obras. Ainda assim, o formato proposto para a escola permite perceber clara afinidade com as ideias socialistas defendidas por ele.

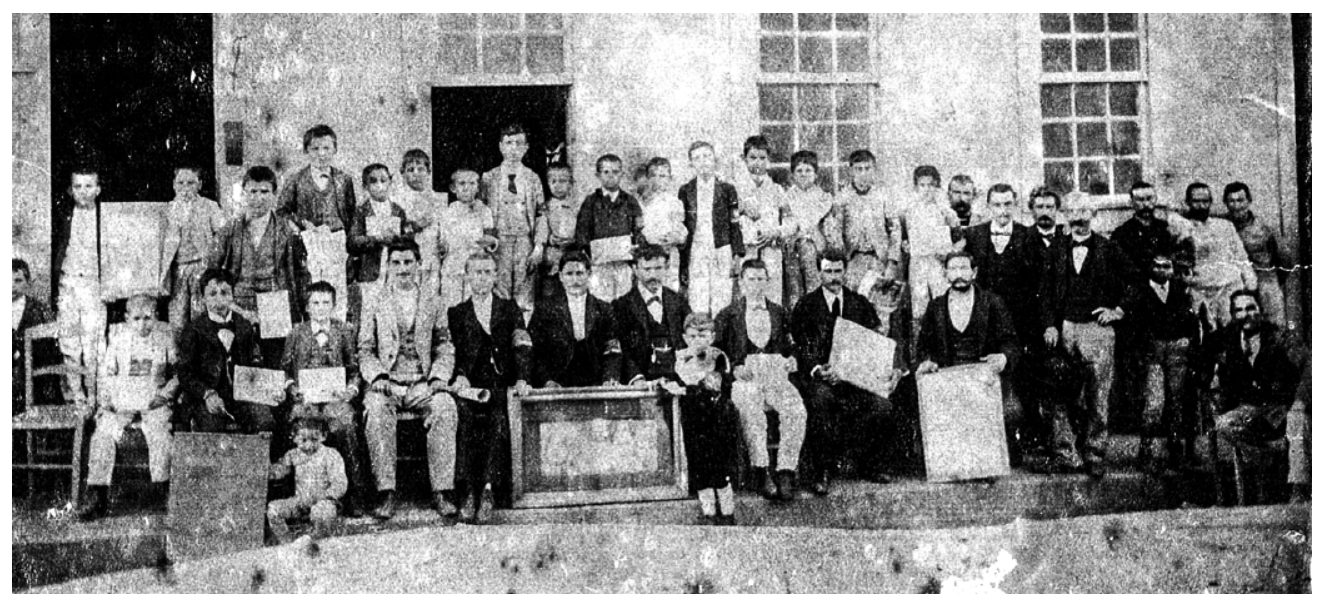

Figura 1 - Alunos da escola de desenho de Paschoal Artese, início do século XX. Fonte: arquivo do Centro da Memória Rio-Pardense Rodolpho José Del Guerra.

Na chamada do jornal em que foi anunciado o início das aulas, ${ }^{34}$ a justificativa era a importância do desenho e da representação para o operariado, com base no projeto pedagógico francês de artes decorativas. Este projeto privilegiava o movimento art nouveau enquanto discussão estética e política apoiada pelo governo como parte do processo de consolidação da República ${ }^{35}$ e da "imagem do país como centro mundial do bom gosto e da produção refinada, artesanal, vanguardista". ${ }^{36}$ Assim, a natureza, conforme a análise de Durant, ${ }^{37}$ nho pedagógico no Ginásio Estadual Euclides da Cunha, onde permaneceu até a sua aposentadoria, em 1973, vindo a falecer em 1982 nessa mesma cidade (TREVISAN, 1995).

30. Cf. Trevisan (1977).

31. Artese, op. cit., p. 9.

32. Segundo o "Diccionario da língua portugueza" (Silva, 1877 , p. 669), a definição de entalhador é "official de obra de talha que entalha, e representa em madeira laçarias, flores, folhagens, brutescos, etc. de meio relevo".

33. Aula nocturna para.. (1900, p. 2).

34. Ibid.

35. Cf. Silverman (1989).

36. Lima (2001, p. 4).

37. Cf. Durant (1986). 
38. Sobre o art nouveau, cf. Ramalho (1989), Lemos (1989) e Motta (1965). Sobre $\mathrm{o}$ arts and crafts, cf. Pinheiro (2011); Naylor (1971).

39. Cf. Barbosa (1978).

40. Cf. Lima (2001, 2008).

41. Ibid.

42. Cf. Bittencourt (1967).

43. Cf. Lemos (1989).

44. Cf. Lima (2008).

45. Cf. Barbosa (1978).

46. Lima (2008, p. 162).

47. Cf. Lima, 2008; Barbosa, op. cit.

48. Cf. Belluzzo (1988). passou a ser considerada uma fonte de inspiração para a criação de padrões ornamentais e decorativos que, sob a referência do arts and crafts, foram estilizados e incorporados pelo art nouveau. ${ }^{38}$ Ambos os movimentos foram linhas-mestras para Paschoal Artese, que favoreceu o intercâmbio entre o desenho de ornato, geométrico, vegetal e de figura como campo propício a criações e combinações.

O ensino das artes e do desenho como parte do currículo escolar foi destacado por Ana Mae Barbosa ${ }^{39}$ e Solange Ferraz de Lima. ${ }^{40}$ Ainda que a discussão proposta por Lima não tenha sido especificamente sobre essa questão, ela a incluiu ao analisar as "artes decorativas" e sua relação com a arquitetura, novos modos de apreensão e percepção da cidade e trânsito de repertórios, enciclopédias, manuais e guias de estilos europeus no Brasil. Ainda segundo Lima $^{41}$ reforçando o exposto por Gean Maria Bittencourt ${ }^{42}$ e Carlos Lemos, ${ }^{43}$ o marco desse ensino no país ocorreu com a vinda da Missão Artística Francesa em 1816. Todavia, a tentativa de sua implementação para habilitar todos os artesãos ao trabalho artístico não obteve o sucesso desejado, possivelmente porque, no contexto do escravismo, o trabalho manual ou artesanal era ostensivamente desprezado. ${ }^{44}$ Somente após a fundação da Academia Imperial de Belas Artes é que o ensino das artes foi concretizado, e o ornato transformou-se em elemento presente nas diferentes disciplinas, atividades e resenhas manuais, nas aulas de desenho e nos trabalhos produzidos e expostos anualmente, embora tal programa continuasse a distinguir claramente $\mathrm{o}$ trabalho do artista e do artífice. ${ }^{45} \bigcirc$ conteúdo curricular tendia a favorecer a educação visual, e a representação do ornato a se desvincular do produto final, tornando-se um modelo - "mudança fundamental, que a produção industrial seriada iria introduzir". ${ }^{46}$ Tratava-se de um contexto muito mais europeu do que brasileiro de indústria nascente, mas que se justificava pela implementação de planos pedagógicos oriundos daqueles países, por exemplo, o programa-tipo de ensino de desenho da Bélgica e da França, que priorizava a observação, o método, a disciplina e a experimentação. ${ }^{47}$

Ana Maria de Moraes Belluzzo, ${ }^{48}$ em seu estudo sobre a relação entre arte, artesanato e indústria no trabalho do Liceu de Artes e Ofícios de São Paulo, destaca que a valorização estética atribuída ao ornamento e o modelo de ensino adotado, que fragmentava os elementos dos diversos estilos, acabaram por interferir diretamente na construção civil, uma vez que o liceu tinha como objetivo preparar artesãos e operários, conforme exposto no Congresso Internacional de Desenho de 1906:

O estudo de medidas que tornem para o futuro obrigatórios a todos os estudos fundamentaes de geometria, perspectiva e architectura elementares qualquer que seja a indústria a qual se destinem. Preparação previa de grande alcance para os operarios chamados a executar 
composições decorativas. Na escola de arte decorativa, o desenho, a modelagem, a geometria, a perspectiva, a architectura elementar, o estudo dos estylos, devem ser incluidos como disciplinas essenciaes e obrigatorias; na escola de artes e officios a educação esthetica dos futuros operarios deve ser ministrada a par com a educação profissional. ${ }^{49}$

O desenvolvimento de uma cultura escolar e de um modelo pedagógico estava associado ainda à formação do gosto, à distinção social e a critérios de valor, visibilidade e valorização da estética, ${ }^{50}$ condicionados pelas possibilidades de produção, circulação e consumo. Nesse cenário, a arquitetura se tornou objeto central de aplicação do ornamento, e sua produção foi campo propício à inventividade de artesãos e operários que seriam satisfatoriamente capacitados à produção.

Relevante para a formação e o aperfeiçoamento da percepção visual e da habilidade manual do operário, esse processo pedagógico avançou para o interior paulista - a exemplo do trabalho iniciado por Artese em 1900 na cidade de São José do Rio Pardo -, o que evidencia não somente o trânsito de informações, mas o valor estético de uma cultura material que marcou a composição de fachadas do final do século XIX e início do XX. A iniciativa de Artese, entretanto, se mostrava sui generis, devido ao viés fortemente socialista. Embora muitos detalhes de sua trajetória sejam desconhecidos, sabemos que foi ainda na Itália que ele teve as primeiras oportunidades de conviver em um ambiente de emergência de organização de classe, dedicando-se ao amparo de trabalhadores e à luta de classes. ${ }^{51}$ Foi com essas ideias, e em um cenário considerado hostil a operários, sobretudo trabalhadores do campo, que Artese se associou a outros italianos residentes em São José do Rio Pardo, como Paschoal Cerávolo, com quem já havia estabelecido vínculo profissional, na defesa "dos oprimidos, da classe desfavorecida", 52 através do Clube Democrático Internacional Filhos do Trabalho ${ }^{53}$ e dos jornais $O$ Proletário (1900-1902), A Defesa do Povo (1917) e a Resenha (1922-1965).

Essa postura tornou Artese alvo de perseguição por aqueles que detinham o poder local. O primeiro processo ocorrev em 1901, quando foi criminalizado com base "no artigo 184 do Código Penal" 54 pelos fazendeiros cafeicultores Cel. Francisco Soares de Camargo, Elisário Luiz Dias e Oliveiros Fernandes Pinheiro por supostamente ter enviado cartas ameaçadoras. Artese respondeu às acusações com uma carta aberta, publicada no jornal O Rio Pardo, em que prenunciava as tentativas da elite local de difamá-lo para desqualificar suas ações em defesa dos direitos dos proletários, conforme segue:
49. Congresso Internacional de Desenho apud Lima (2008, p. 164).

50. Cf. Asendorf (1984).

51. Cf. Del Guerra (1999).

52. O Proletário apud Del Guerra (1999, p. 36).

53. Fundado em 25 de setembro de 1900, o Clube Democrático Internacional Filhos do Trabalho era ideologicamente ligado ao círculo socialista Avanti, de São Paulo, e tinha como principal representante Paschoal Artese. Em 1909 o Clube encerrou suas atividades, extinguindo-se a última agremiação socialista rio-pardense. Sobre o Avanti e sua importante atuação no lançamento das bases do sindicalismo italiano no Brasil, cf. Toledo (2002). Outra importante contribuição para o entendimento do sindicalismo italiano é o trabalho de De Felice (1966).

54. Del Guerra (1999, p. 36). 
55. Ibid., p. 37.

56. Cf. Rykwert (1982).

57. Paschoal Artese afirmou em uma das edições do Jornal $O$ Rio Pardo que frequentou como aluno a "'scuola di arte e Mestieri', com regular e legal diploma da Esc. de A. e M. de Monteleone Calábria” (AULA NOCTURNA PARA..., 1900, p. 2). Provavelmente era uma escola de ofícios, e não de ensino superior, e dificilmente seria possível comprovar a sua existência ainda hoje. Esta suposição ganha ainda mais fundamentação ao recordarmos que Paschoal Artese chegou em São José do Rio Pardo com "cerca de quinze anos", conforme declarado por ele próprio (cf. ARTESE, 1966, p. 9).

58. Cf. Debenedetti e Salmoni (1981), Fabris (1987) e Lemos (1989). Exemplo é a versão reduzida e simplificada, intitulada "O Vignola dos proprietários", traduzida por José da Fonseca, que teve ampla circulação entre os profissionais da construção civil.
[...] a infâmia praticada tem manifestamente por fim procurar tornar-me odiado e trazer, ao mesmo tempo, o descrédito do partido Socialista do qual pertenço. [...] É preciso que os leitores saibam: o partido socialista não é perturbador da ordem e nem procura a desarmonia entre patrões e trabalhadores [....$^{55}$

Mas, além de ativista político, Artese se empenhou em construir uma carreira profissional independente. Foi assim que em 1902, após o encerramento da parceria com Cerávolo, ele abriu a sua própria marcenaria, a Vibonese, que aceitava "encomendas de obras, mobílias de todos os estilos, obras de entalhe, etc. [...] na moda nacional, argentina e europeia", a partir de modelos escolhidos pelos fregueses nos catálogos. Artese investiu também na criação de uma olaria, denominada Fartura, para produzir telhas e tijolos, e em um depósito, para comercializar principalmente cal, cimento, manilhas e mosaicos. Paralelamente, Paschoal oferecia projetos de reforma e construção, planejados e executados em "ordem architectonicas e em estylos modernos", referindo-se à arquitetura clássica e ao que havia de mais avançado, possivelmente o art nouveau, ou ainda de acordo com o "gosto do cliente". Em seus anúncios, conforme é possível observar na Figura 2, ele se referia a "pontualidade e garantia pelas empreitadas", colocando-se como um profissional que valorizava o cumprimento do cronograma da obra e a qualidade do serviço oferecido. Ao informar que "executa e vende qualquer ornamento em cimento ou gesso para frente de prédios, sejam, como capitéis, cimalhas, balaústres, cantoneiras, etc.", certamente queria dizer que fabricava tudo o que era utilizado em suas obras, ou ainda o que era encomendado por clientes, que podiam consultar catálogos e modelos em seu escritório bem localizado, entre o Grupo Escolar Cândido Rodrigues e o Jardim Artístico, no Largo do Grupo Escolar (atual Praça Barão do Rio Branco, no 156). Além disso, ao descrever tais elementos, Artese demonstra domínio da linguagem clássica e discernimento de sua propagação como modelo de bom gosto, 56 conhecimento que indubitavelmente adquiriu em sua vivência e estudos na ltália ${ }^{57}$ e através dos manuais inspirados nas Regras das cinco ordens de Arquitetura de Vignola, que circularam no mundo inteiro e foram amplamente difundidos no Brasil. ${ }^{58}$

Artese condicionou sua produção às novidades e às possibilidades técnico-construtivas, projetando e executando com base na arquitetura clássica e no art nouveau, a partir da decomposição dos elementos e aplicação de ornamentos ressignificados como unidades decorativas. A variedade de motivos e estilos, associada à liberdade de criação, permitiu a Artese desenvolver certa originalidade em seu ecletismo, constatada nos remanescentes de sua produção, contribuindo ainda para o estabelecimento dessa linguagem plástica localmente, algo semelhante ao que ocorreu na cidade vizinha, Mococa, com a atuação de 
Gherardo Bozzani. ${ }^{59}$ Dentre as várias obras de Artese, destacam-se: as moradias de Dante Artese, na praça Barão do Rio Branco, n 142, e n 182 lambas da década de 1910l; de Beatriz Cristina Granado do Prado, na avenida Independência, n 5 (1917-1918); uma casa na rua Francisco Glicério, n 546 (década de 1910); a residência da família Bincoletto, na praça XV de Novembro, $n^{\circ} 42$ (por volta de 1915); e o edifício de uso comercial e residencial da família Landini, na rua Treze de Maio, n 146-152 (década de 1910) (Figura 3).

\section{Aviso intoressante}

Acaba de ser installada na Fartura uma Olaria movida a vapor, que desde jú esta em condiçues de fornecer a quem precisar bons materiaes para construcprecisar

Os tijollos e as telhas são de uma solidez estraordinaria, devido a superioridade da argilla. As dimensôes são maiores que qualquer outra marca existente reste municipio.

Os interessados que precisarem de qualquer quantidade destes materiaes deverāo entender-se com o seu proprietario Paschoal Artese, que garante serem os preços commodos e a qualidade extrasuperior.

A gerencia desta Olaria está eonfial da ao snir. Umberto dal Bello, oleiro peritona sua profissão, tendo longa pratica. Telephone de P. Artese n. 175. da Olaria $n .18 \mathrm{x}$. S. Joné do Rio Pardo

\section{Secçáo Livere \\ Paschoal Artese \\ CONSTRUCTOR}

Encarrega-se de levantaf projectos para reformas e coristruç̧⿸尸o de predios, seja em ordem architectonicas e em estylos modernos; execu. ta-se por empreitada ou ad. ministragato.

PONTUALIDADE E GARAN. TIAS PELAS EMPREITADAS,

Executa e vende qualquer ornamentaçăo $\mathrm{em}$ cimento ou gesso para frente de predios, sejarn, como capiteis, cima. lbas, balaustres, cantoneira etc, etc.

Escriptorio em sua propria residencia, no largo do Grupo Escolar.

S. Josế do Rio Pardo.
59. Sobre a produção arquitetônica mocoquense, e de modo especial as obras de Gherardo Bozani, cf. Ribeiro (2011).

Figura 2 - Anúncios da marcenaria Vibonese, olaria Fartura, depósito de material para construção e serviços oferecidos como construtor por Paschoal Artese. Fonte: $O$ Rio Pardo, 5 de abril de 1902, 8 de novembro de 1913 e 5 de abril de 1912. 


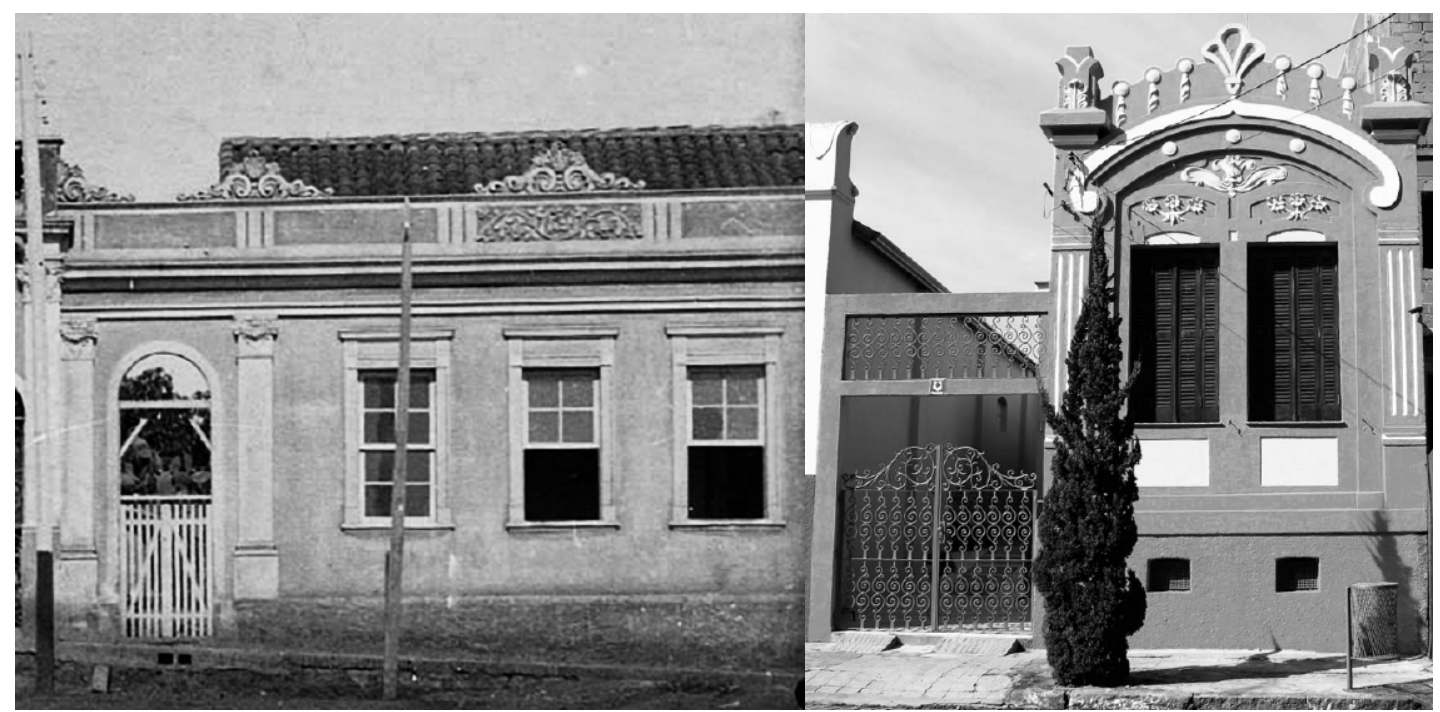

Figuras 3a (moradia de Dante Artese na Praça Barão do Rio Branco, $n^{\circ} 142$ ) e Figura 3b (moradia na praça Barão do Rio Branco, $n^{\circ}$ 1821

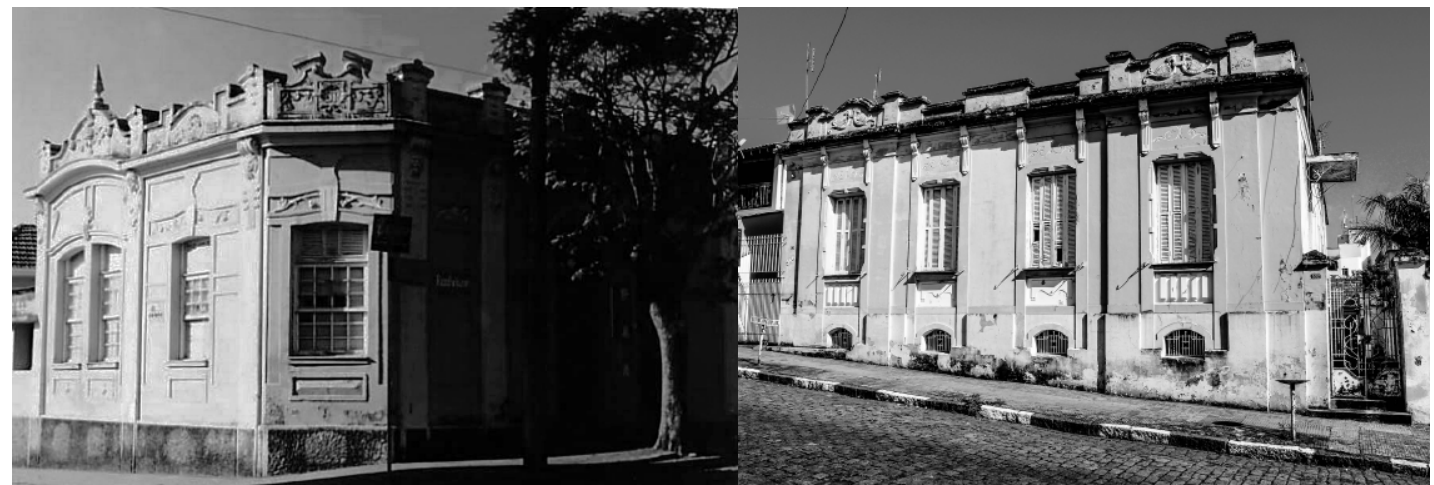

Figura 3c (moradia de Beatriz Cristina Granado do Prado na Avenida Independência, n⿳5) e Figura 3d (moradia na Rua Francisca Glicério, n546).

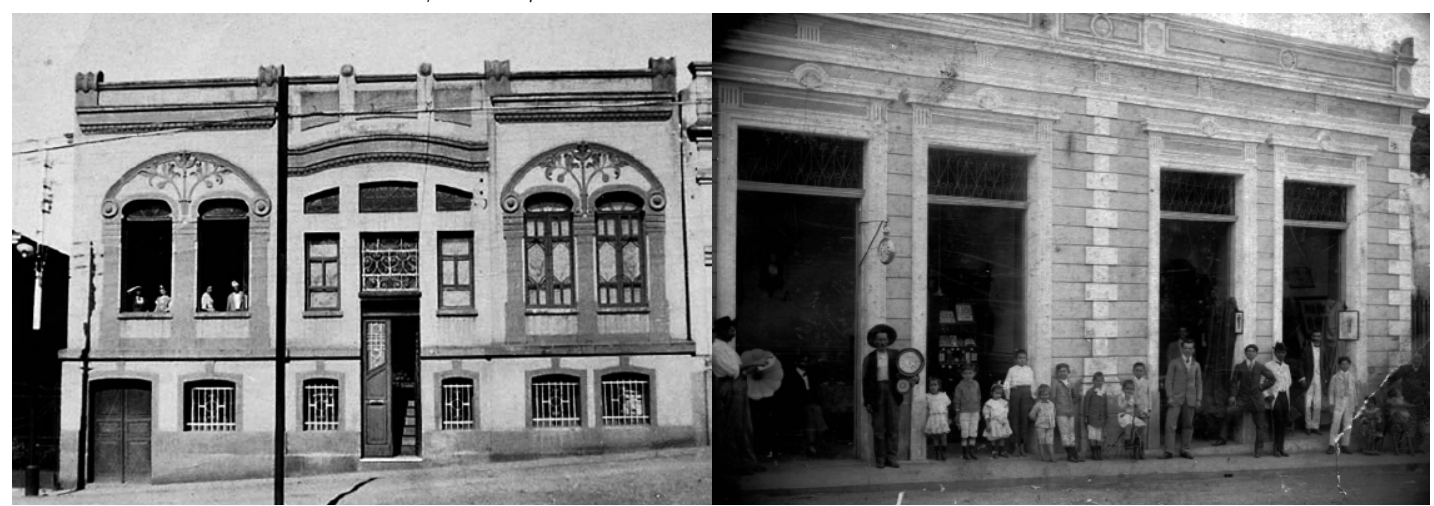

Figura 3e (moradia da família Bincoletto na Praça XV de Novembro, n42) e Figura $3 f$ (edifício de uso misto da família Landini na Rua Treze de Maio, $n^{\circ}$ 146-1521 - Edificações projetadas e construídas por Paschoal Artese no início do século XX. Fonte: arquivo pessoal de Natalia C. Rezende e Arquivo do Centro da Memória Rio-Pardense Rodolpho José Del Guerra. 
Ao analisar essas obras, constatamos a perspicácia de Artese para dar monumentalidade à fachada, como principal elemento de expressão da individualidade e do lugar social do morador. ${ }^{60}$ Sua maestria nesse aspecto pode ser constatada na residência da família Bincoletto, ${ }^{61}$ em que a edificação ocupa toda a testada do lote, mas cria afastamentos laterais posteriores, como recurso para garantir ventilação cruzada e iluminação natural aos ambientes. Essa solução estava além das exigências do Código de Posturas local, que fazia referência apenas à "observância a hygiene e segurança das obras e ao embellezamento da cidade", e à necessidade de "preenchimento das condições impostas pelo Código Sanitário do Estado, especialmente as do Cap. II, sobre as habitações em geral". ${ }^{62}$ Este código, por sua vez, proibia a existência de alcovas que se destinassem a dormitórios ou à permanência constante de moradores, e destacava a exigência dos ambientes possuírem aberturas para o exterior, de modo a receber luz direta, mas nada citava sobre ventilação natural e cruzada. A estratégia de Artese em criar esses afastamentos nas duas laterais, posteriores aos ambientes fronteiriços, assegurou condições muito satisfatórias de higiene e salubridade, em decorrência da iluminação direta dos cômodos e da troca de ar. Além disso, nas edificações projetadas e construídas por ele e apresentadas neste trabalho, o porão de no mínimo $50 \mathrm{~cm}$ de altura estava sempre presente, conforme estabelecia o Código Sanitário Estadual em seu artigo 44.63 Essa medida visava o afastamento do piso do andar térreo em relação ao solo para evitar a umidade ascendente, amplamente denunciada por médicos e engenheiros por ser considerada potencializadora de doenças e causadora de muitos prejuízos materiais. ${ }^{64} \bigcirc$ porão e as estratégias criadas por Artese para suprir os ambientes de luz e ventilação direta e cruzada deixam evidente seu domínio do ofício de projetar e construir.

Artese também foi um valoroso artífice que exercitou a liberdade criativa nas fachadas e na ornamentação de suas obras, inovando ao combinar variados arranjos, como é possível constatar no sobrado construído para ser sua moradia, na praça Barão do Rio Branco, n 156, no início da década de 1910, que ficou popularmente conhecido como Casarão do Artese (Figura 4). Localizado nas proximidades do Grupo Escolar Cândido Rodrigues, este foi o primeiro edifício de grande dimensão e importância construído por Paschoal em São José do Rio Pardo. No prédio, destaca-se a riqueza de detalhes na composição da fachada principal, marcada pela disposição ritmada das molduras das aberturas em arco pleno, verga reta e arco ogival. As pilastras e os pilares, que remetiam às ordens coríntia e jônica, demonstram mais uma vez que Artese no mínimo detinha noções básicas da gramática clássica. Todo o peitoril da sacada e da varanda era decorado com balaustrada, enquanto a platibanda era marcada pela composição
60. Cf. Fabris (1993)

61. Essa edificação foi construída na década de 1910 , segundo Zveibil (2000), após encomenda feita a Paschoal Artese pelo fazendeiro Manoel Ribeiro Machado. A família Bincoletto foi a última proprietária da edificação até ela ser doada para a Igreja Católica na década de 2000.

62. São José do Rio Pardo (1903, p. 5-6).

63. Aparentemente, a edificação da família Landini não possui porão para quem a observa da rua, uma vez que Artese aproveitou a declividade do terreno para o fundo do lote para instalar o depósito.

64. Cf. Correia (2004). 
65. As Figuras 6 e 7 compõem uma série de fotografias que foram realizadas em 2006 por um grupo de estudantes que visitaram o edifício já em ruínas acompanhados pelo professor Antônio Carlos Lorette, que nos cedeu o material. livre de elementos florais. Algumas dessas características foram realçadas e outras apenas alteradas no início da década de 1920, quando o próprio Artese reformou o Casarão a fim de ampliá-lo (Figura 5), adotando uma profusão de elementos decorativos com figuras mitológicas e da natureza. Com efeito, as molduras das esquadrias e a sequência rítmica de pilastras foram suprimidas; a balaustrada da varanda foi substituída por elementos mais delgados; as molduras em arcos ogivais deram lugar a arcos abaulados e encimados por ornatos floreais; e a platibanda foi mais valorizada, como elemento de maior sofisticação na fachada, especialmente nos volumes laterais, com a inclusão de uma pequena viga em semicírculo arrematada pelo alteamento dos pilares. A composição apresentou arranjos volumétricos marcados pelo contraste entre cheios e vazios, com ornatos claramente inspirados no estilo art nouveau, particularidades que podem ser verificadas na Figura 6. ${ }^{65}$ Essa cosmetização da fachada escancarava as pretensões e condição social do morador, ao mesmo tempo em que mostra como Artese estava atualizado em relação ao que havia de mais avançado em termos estéticos da época, alinhando-se ao movimento de modernização da paisagem urbana local, da qual ele mesmo era um dos grandes responsáveis.

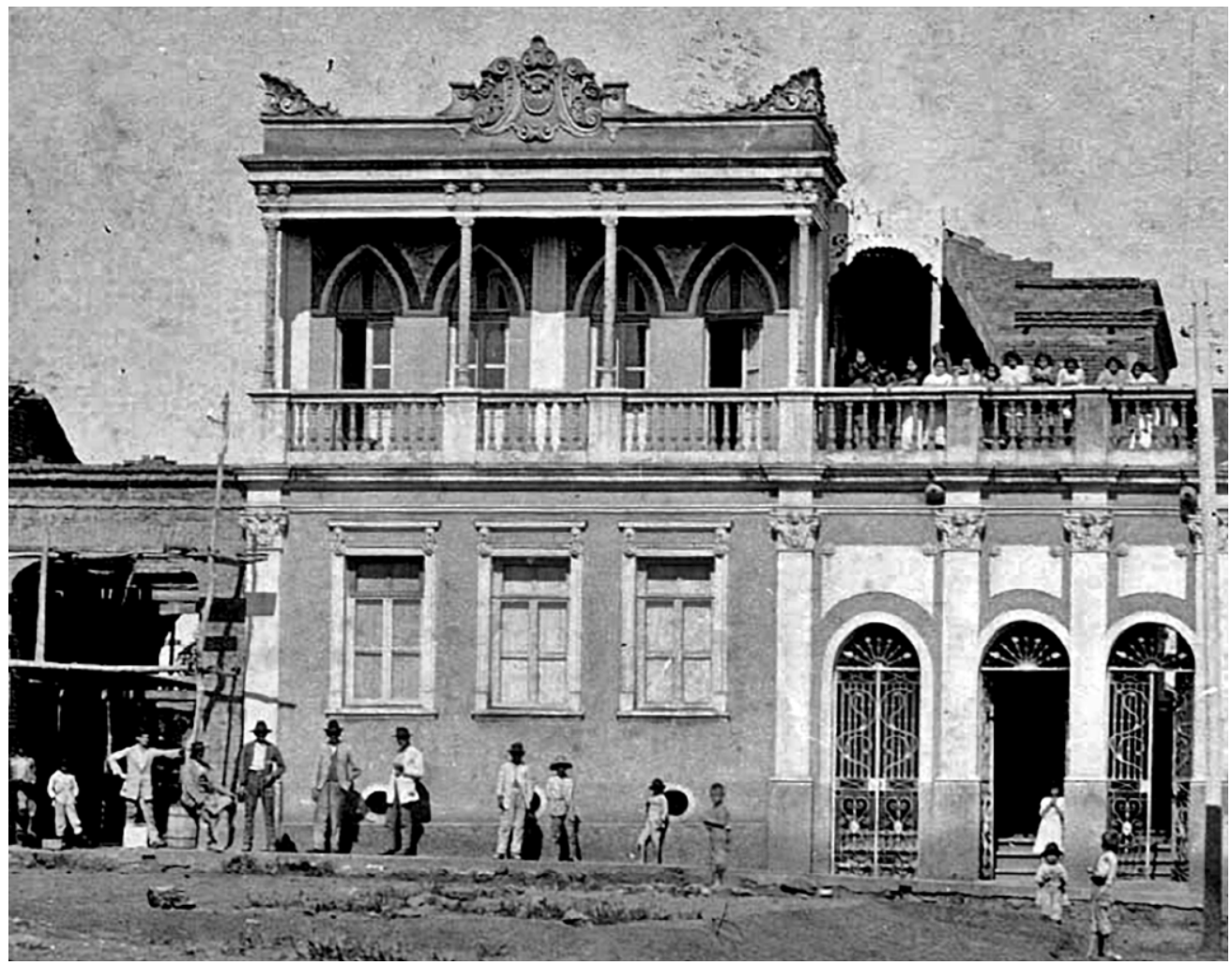

Figura 4 - Casarão do Artese construído na praça Barão do Rio Branco, n 156, década de 1910. Fonte: arquivo do Centro da Memória Rio-Pardense Rodolpho José Del Guerra. 


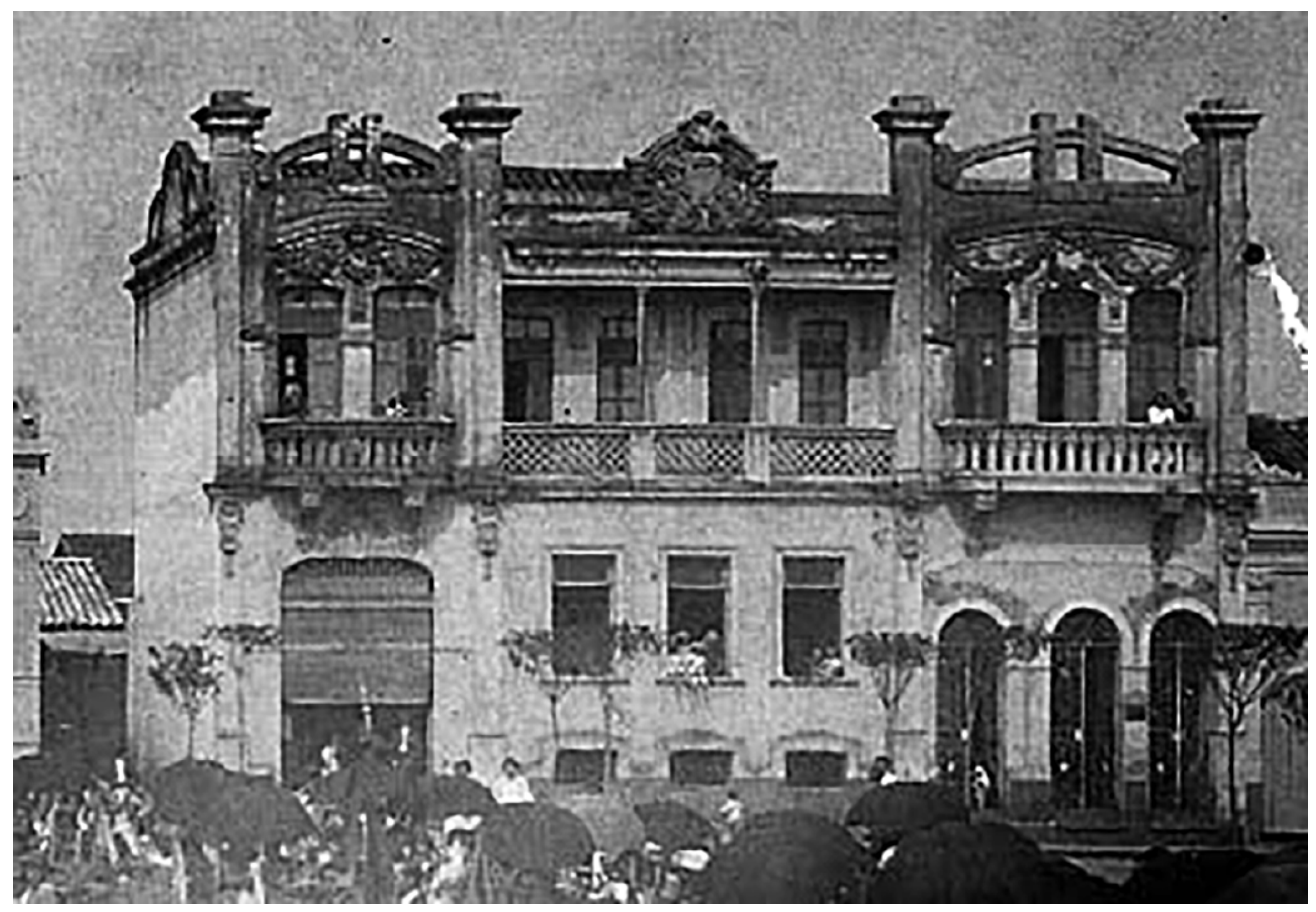

66. Cf. Salvadore (2015).

67. Cf. Lima (2008).

68. A exemplo da tese que trata das moradias urbanas de São Carlos no ciclo cafeeiro (BORTOLUCCI, 1991).

69. Cf. Torres (1979).

70. Cf. Monteiro (2009).

Figura 5 - Casarão do Artese reformado e ampliado, 1922. Fonte: arquivo do Centro da Memória Rio-Pardense Rodolpho José Del Guerra.

É grande a erudição do italiano, a ponto de se mostrar ainda conhecedor do estilo florentino na arquitetura, reconhecido como expressiva variante do ecletismo paulistano, a mais incisiva ${ }^{66}$, muito presente em suas obras. A título de exemplo, Lima ${ }^{67}$ apresenta em seu trabalho uma moradia eclética florentina, localizada na rua Canuto do Val, no bairro de Santa Cecília, que muito se assemelha às edificações construídas por Artese e por outros profissionais no interior paulista. ${ }^{68} \mathrm{Na}$ Figura 3, é possível perceber essa referência no desenho que compõe as aberturas da casa da família Bincoletto.

Em se tratando de técnica construtiva, no Casarão, antes e depois da reforma, e em todas as outras obras, Artese utilizou alvenaria de tijolo provavelmente produzido em sua olaria, o que o torna também fornecedor de matéria-prima para as construções locais, como possivelmente faziam também Grandjean de Montigny, segundo Torres, ${ }^{69}$ e Ramos de Azevedo, de acordo com Monteiro. ${ }^{70}$ Todas as paredes do Casarão foram argamassadas e pintadas, e os ambientes da área social e íntima foram revestidos por pintura em estêncil, com motivos geométricos e florais, seguindo a plástica da fachada após a reforma. Os pisos originais da edificação eram em ladrilho hidráulico, assoalho de madeira e tijolo cerâmico. $\bigcirc$ telhado foi estruturado com madeira serrada e coberto com telha capa e canal. 
Piso e forro cumpriam também a função de hierarquizar os ambientes, apresentando desenhos de formas variadas nos cômodos sociais e íntimos, enquanto nos demais havia um simples tabuado de madeira lisa corrida. Já as esquadrias eram de madeira, enquanto aquelas de maior destaque eram de ferro forjado e fundido, como estratégia de hierarquização e qualificação de fachada juntamente com a platibanda. Todas possuíam bandeiras fixas, também em ferro, que permitiam a iluminação e a ventilação natural (Figura 6 e figura 7).
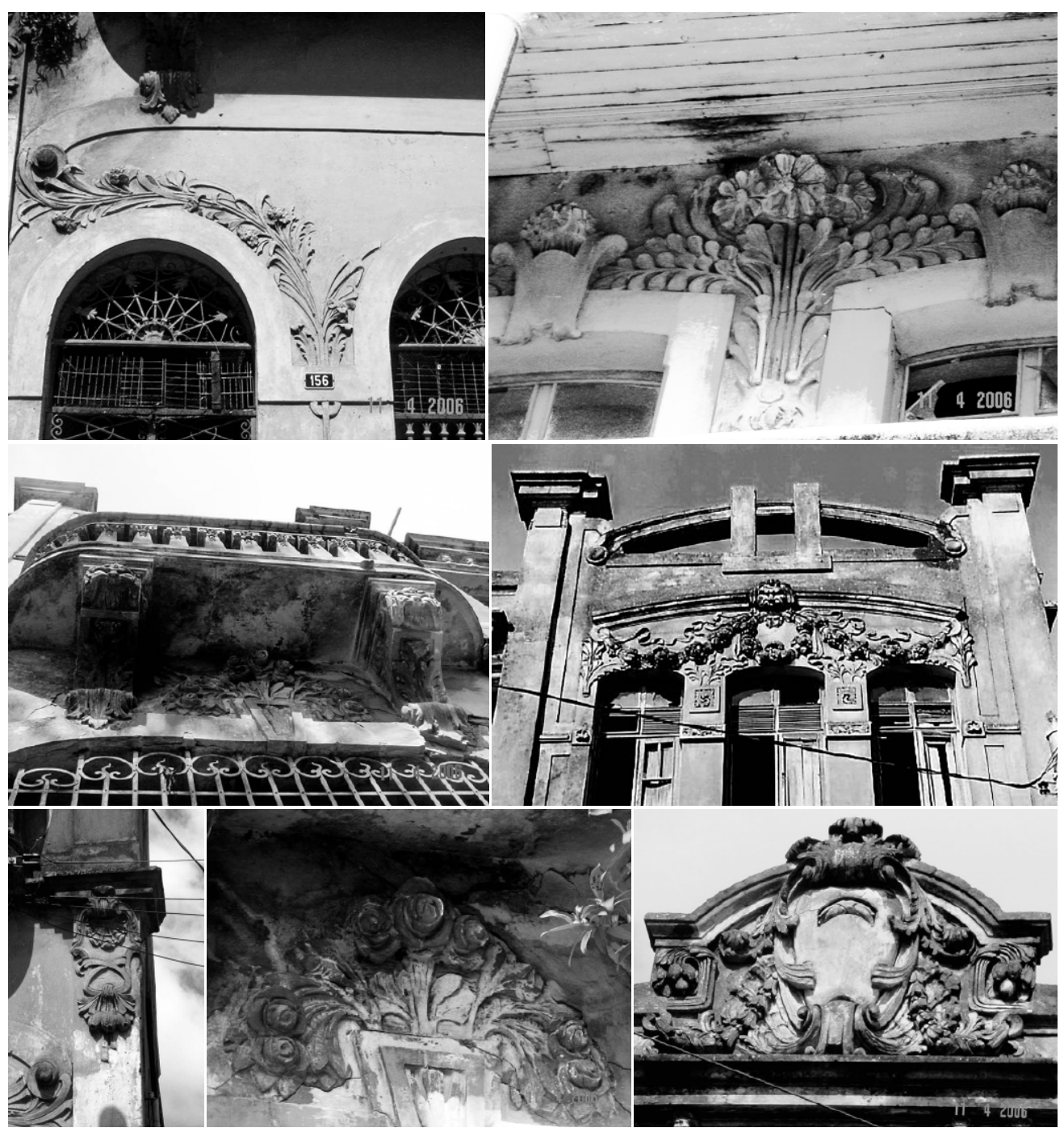

Figura 6 - Ornamentos do repertório floreal utilizado por Paschoal Artese em sua residência na praça Barão do Rio Branco, n 156. Fonte: acervo pessoal de Antônio Carlos Lorette (2012). 


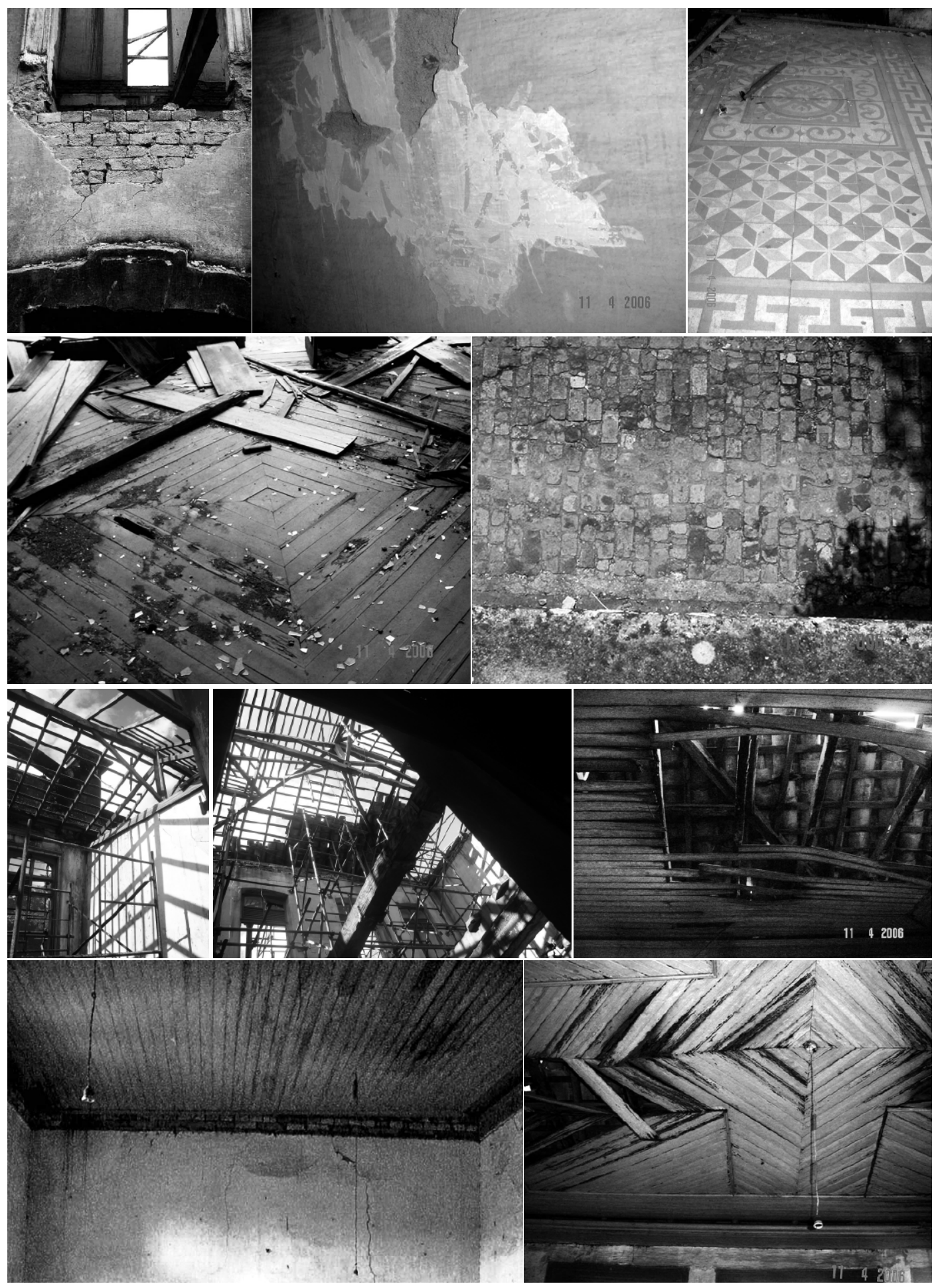

Figura 7 - Materiais e técnicas construtivas utilizadas por Paschoal Artese. Fonte: acervo pessoal de Antônio Carlos Lorette (2012). 
71. Cf. Costa (2001)

72. Cf. Silva (1986).

73. Cf. Marins (2001).

74. Paulo Fernandes Vianna fazia parte do Conselho de Príncipe Regente Nosso Senhor, foi Desembargador do Paço e Intendente Geral da Polícia da Corte e do Estado. Para saber mais, cf. Marins, op. cit e Lemos (2012).

75. Costa, op. cit.

76. Silva, op. cit.

77. Cf. Bruno (1984).

78. Cf. Freyre (1948).
Igualmente à ornamentação aplicada nas fachadas com referenciais classicizantes e floreais, os gradis e portões utilizados nas obras de Artese apresentavam um rico trabalho de curvaturas, sinuosidades, motivos da natureza, ou mesmo a combinação destes com a pura geometrização, evidenciando sua competência técnica também na serralheria artística, como pode ser observado nos desenhos produzidos por nós a partir de fotografias e levantamento métrico (Figura 8). Foram utilizados o ferro forjado e fundido, sobretudo nos portões, óculos dos porões, mãos francesas e esbeltas colunas ornamentadas.

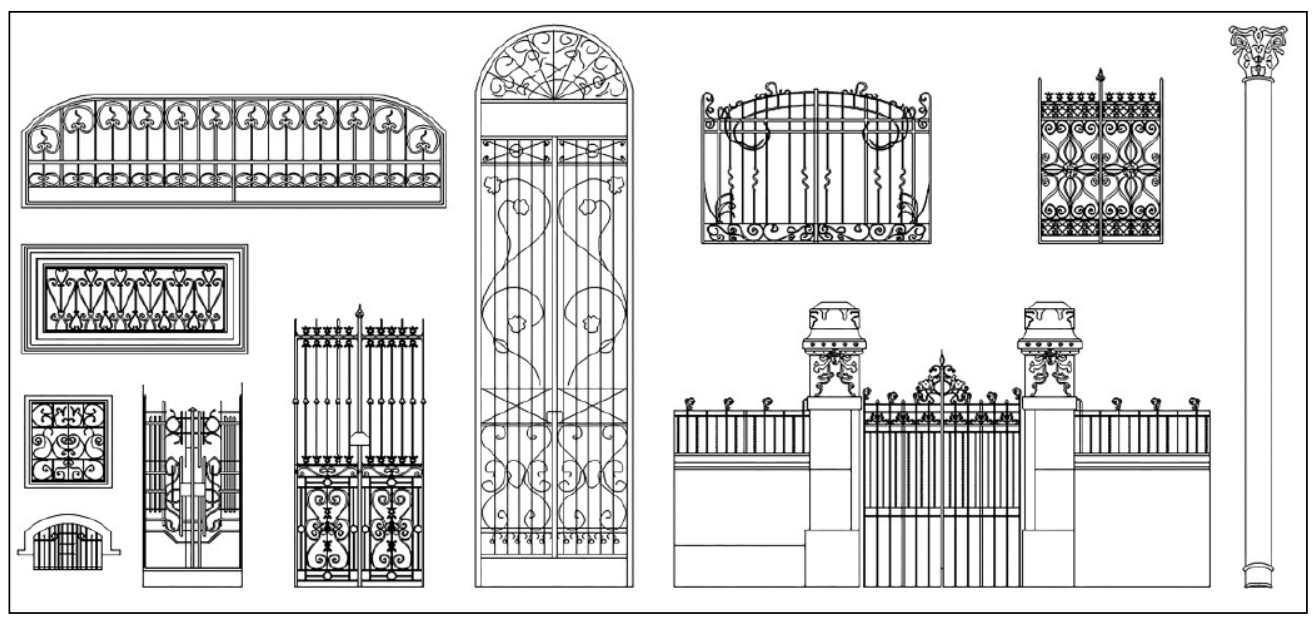

Figura 8 - Gradis e portas de ferro de edificações construídas por Artese. Desenho de Natalia C. Rezende com base em levantamento físico e fotográfico.

Segundo Cacilda Teixeira da Costa, ${ }^{71}$ Geraldo Gomes da Silva ${ }^{72}$ e Paulo Cesar Garcez Marins, ${ }^{73}$ a acentuada utilização do ferro na arquitetura brasileira ocorreu após o mercado nacional, aberto em 1808, tornar-se alvo do comércio da Inglaterra. Nesse momento, d. João Vl, que havia se instalado no Rio de Janeiro, foi pressionado a facilitar o escoamento dos produtos britânicos. Através da figura de Paulo Fernandes Vianna, ${ }^{74}$ um edital foi publicado exigindo a troca de janelas de rótulas e balcões de madeira por gradis ou balaústres em um prazo máximo de seis meses. Costa ${ }^{75}$ e Silva ${ }^{76}$ destacam ainda que esse foi um momento de aspiração ao progresso, à sofisticação, ao enriquecimento e à distinção social, o que levou sobretudo a classe média a usufruir da importação de componentes e até estruturas inteiras da Europa. A substituição das rótulas, balcões e muxarabiês pelas determinações da municipalidade ocorreu ainda induzida por descrições e adjetivações pejorativas em oposição ao refinamento atribuído ao ferro e ao vidro, conforme mostram Ernani da Silva Bruno 77, ao caracterizar as moradias paulistanas do século XIX, e Gilberto Freyre, ${ }^{78}$ em seu estudo sobre o impacto da cultura 
britânica na vida, na paisagem e na cultura do Brasil. Apesar da legislação riopardense não apresentar exigências nesse sentido, Artese revela conhecimento ao fazer uso do ferro como elemento de qualificação da edificação.

No final do século XIX, o aumento da demanda e os custos de produção, considerados relativamente baixos, propiciaram a fabricação interna, surgindo, assim, diversas serralherias que se instalaram nas grandes cidades e no interior paulista. Em São José do Rio Pardo, a serralheria Riopardense, que executava "todos os serviços concernentes ao officio" e fabricava qualquer elemento em "todos os estylos" é um exemplo (Figura 9). Nesse sentido, é razoável que parte dos elementos em ferro utilizados por Artese, principalmente os que empregaram ferro forjado, tenham sido produzidos nas serralherias locais, muito provavelmente inspirados nas peças apresentadas nos catálogos da MacFarlane ${ }^{79}$ que, de acordo com Costa, ${ }^{80}$ foram largamente divulgados no Brasil.

\section{SERRALHERIA

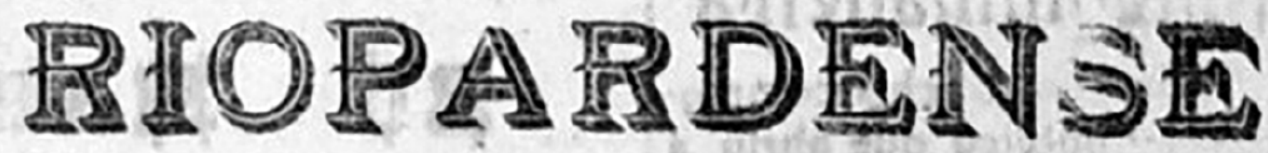 Nicoláo Cosentino \& Carratto \\ Nesta officina exocutam se todos os servi ços concernentes ao officio, como sejam grades a portôes de ferro de todos os estylos, como tambem trabalha.se em canalisaçao de agua, em deposito de ferro $\theta$ serpentinas para agua yuente e fria. \\ Concertam-se armas de fogo e machinas de costura de qualquer systema, etc.}

Figura 9 - Anúncio de uma serralheria em atividade na cidade de São José do Rio Pardo, 1910. Fonte: $\bigcirc$ Rio Pardo, 18 de agosto de 1910.

Ao analisar a produção de Artese em termos estéticos, decorativos e estruturais, é possível perceber o pleno domínio que ele detinha de todo o processo, do desenho ao canteiro, especialmente na aplicação dos artefatos, sendo o ornato
79. Segundo Kühl (1998, p. 75), a MacFarlane se destacou "pela eficiente e racional produção, em larga escala, tanto de estruturas inteiras, quanto, principalmente, de elementos modulares, que davam origem a inúmeras combinações de edifícios para os mais variados fins". Ainda de acordo com essa pesquisadora, $O$ destaque conquistado pela MacFarlane no Brasil ocorreu em razão do competente sistema de distribuição aliado à versatilidade dos seus produtos. Essa questão e a sua ingerência na arquitetura brasileira são abordadas por Silva (1986).

80. Cf. Costa (2001). 
81. Lemos (1987, p. 70).

82. Cf. Lemos (1989) e Reis Filho (2011).

83. A primeira reportagem que o cita como arquiteto data de 4 de setembro de 1904, quando noticiou a inauguração do novo púlpito da igreja Matriz, trabalho realizado em conjunto com o seu irmão Salvador Artese (NOVO PULPITO, 1904 , p. 1). Já a última reportagem encontrada que faz referência a Artese como arquiteto é de 16 de maio de 1909 , por construir um coreto usado para leilões de prenda em benefício da igreja Matriz (FESTA DO MES..., 1909, p. 4).

84. Paschoal Artese foi processado seis vezes entre os anos de 1901 e 1910 , e outras 16 no período de 1914 a 1951. Todos os processos que ele recebeu estavam diretamente relacionados a seu posicionamento contrário a privilégios e monopólios, sendo inocentado em todos.

85. Cf. Pareto Júnior (2011).

86. O jornal Resenha surgiu em 15 de outubro de 1922 como publicação destinada à arte, literatura, propaganda e ciência, sendo o seu lucro revertido à conservação do Jardim Artístico. A última edição provavelmente foi publicada em 1966. Não há documentos que comprovem a data exata dessa última edição, mas sabemos da existência do número 787 , de 17 de dezembro de 1965, com artigos incompletos. Sobre a Resenha, Del Guerra (2002, p. 15) nos diz que "foi um jornal polêmico, publicado irregularmente, que lutou pelo progresso da cidade, apontando falhas, reivindicando a criação de escolas, criticando desacertos de prefeitos". E Trevisan (1977, p. 3a) complementa: "em resumo, não há exage- o elemento que conferiu marca própria a suas edificações. Além disso, é necessário reconhecer que o ecletismo praticado por ele se deu em função da apropriação e reinterpretação do que estava à disposição no mercado, segundo suas próprias preferências estilísticas e o gosto do cliente, porque essa era a linguagem plástica que, segundo Lemos, designava "a licença de criar, de recriar, ou combinar formas, de misturar ornamentações próprias de estilos definidos regionalmente pela Europa afora". ${ }^{81}$ Foi esse excesso de tolerância que deu abertura à participação dos clientes na escolha e na criação da composição arquitetônica, significando a sua inclusão também nesse processo de transformação da paisagem. $\bigcirc$ ecletismo foi ainda a resposta lógica em um momento de efervescência informativa proporcionada pela diversificação editorial, com manuais, repertórios, enciclopédias, catálogos comerciais e guias de estilo e decoração que promoveram a produção e o consumo, induzindo formas de composição arquitetônica. ${ }^{82}$

Indubitavelmente, a qualificação de Artese the permitiu gozar do status de arquiteto em uma cidade e um período carentes de mão de obra de profissionais diplomados. É, portanto, na esteira desse reconhecimento, ainda que em parte devido à indefinição entre termos e categorias profissionais, que Paschoal deixa de ser mencionado em reportagens de jornal como marceneiro, construtor e empreiteiro, passando a ser apontado como arquiteto por algum tempo, mais precisamente entre os anos de 1904 a 1909. ${ }^{83}$ Limitação temporal que nos impõe não necessariamente respostas, e sim suposições, dentre as quais sua atuação militante e embates com membros da elite local, que detinham grande poder econômico e político, o que resultou em diversas tentativas de levá-lo a descrédito. ${ }^{84}$ Consequentemente, é possível que tenha ocorrido a dissolução de um capital social que ele engendrou ao oferecer qualificação de mão de obra para atuar na construção civil conjuntamente com obras e materiais de qualidade.

Para além de questões que dizem respeito mais ao anacronismo de terminologias, categorias e relações de poder, ${ }^{85}$ há ainda um contexto de pressão pela regulamentação do exercício profissional de engenheiro e arquiteto, sobretudo após a década de 1920. Isso certamente contribuiu para que Artese desistisse da atuação na construção civil rio-pardense, mas não da militância, dedicando-se quase que exclusivamente a dirigir e redigir seu jornal, a Resenha. ${ }^{86}$

Antes disso, principalmente na década de 1910, Artese estendeu suas ações e contribuiu de outras formas para o desenvolvimento material da cidade, por exemplo ao promover quermesses a fim de arrecadar fundos para a conclusão de obras, como a do hospital Santa Casa de Misericórdia, ${ }^{87}$ ou ao realizar intervenções urbanas, abrindo e prolongando logradouros, como ocorreu com as ruas Treze de Maio, Campos Salles, Jorge Tibiriçá, Rio Pardo e a avenida 
Independência. Obras que Paschoal fez questão de destacar ao rejeitar a homenagem recebida na Câmara Municipal em 1966:

Passamos a trabalhar incansavelmente para o desenvolvimento da cidade. Promovemos quermesses a fim de concluir obras do interesse público que se achavam paralisadas por falta de verba; incrementada a abertura de novas ruas para as quais chegamos a ceder terreno nosso; ruas que desejávamos ver abundantes, extensas, desimpedidas, em defesa das quais, sempre protestos solenemente, quando algum prefeito tacanho, ou chefe político retrógrado as trancavam, atravessando-lhe grandes prédios no caminho, como que proibindo que o progresso fosse mais adiante... ${ }^{88}$

Artese também idealizou e manteve outra grande obra de impacto na cidade, o Jardim Artístico, construído no local do antigo cemitério, que foi aterrado com material retirado da praça Barão do Rio Branco, diminuindo o desnivel que havia entre a rua Francisquinho Dias e a rua Treze de Maio. Foi a partir de preceitos estéticos e sanitários ${ }^{89}$ que uma comissão organizada por Artese promoveu uma subscrição pública de arrecadação de fundos para construir esse jardim. A reportagem do jornal $\bigcirc$ Rio Pardo do dia 1 de fevereiro de 1913 atesta a contratação dos serviços prestados por João Dierberger: ${ }^{90}$

[...] vai ser contractado para construcçáo do jardim, o snr. João Dierberguer, proprietário da Loja Floricultura da Capital. [...]. Torna-se, por conseguinte, uma necessidade urgente fazer sahir dequelle lugar o velho campo santo, e isso em respeito aos nossos semelhantes e afim de não se continuar a ver tal profanação aos mortos. Em nome da memória dos que ali reposam no ultimo sonno, em nome da civilização e do progresso, espera o abaixo assignado que V. S. concorra e faça concorrer os seus amigos e parentes qualquer quantia para fazer face as despesas necessárias. ${ }^{91}$

Desta maneira, o jardim, ${ }^{92}$ de inspiração pitoresca e vegetação exótica, com fontes ornamentais, carrancas, conchas e leões encomendados da capital paulista ao escultor Vicente Larocca, ${ }^{93}$ passeios serpenteados e estátuas de mármore importadas da Itália, de Pietrasanta, foi sendo construído paulatinamente (Figura 10). As pretensões de Artese para esse jardim eram grandes, assim como os obstáculos impostos pelos governos municipais, conforme o próprio Artese fez questão de enfatizar em seu discurso, dizendo que em

certa ocasião sonhamos dotar a cidade de um lindo jardim [...]. Já bem dentro do perímetro urbano, havia um velho cemitério cercado de paredões derruídos, tétrico, em ros em dizer-se que não houve acontecimento sócio-cultural de que, através de seus jornais, Paschoal Artese não participasse, seja apresentando, apoiando ou contrariando iniciativas".

87. O projeto do hospital Santa Casa de Misericórdia foi elaborado pelo dr. Horácio de Almeida Rodrigues e oferecido por intermédio de Tarqüínio Cobra Olyntho, sendo os serviços de execução confiados a Paschoal Artese, que os concluiu em 1913 (DEL GUERRA, 2001).

88. Artese (1966, p. 10).

89. O paisagismo foi incorporado ao espaço urbano associando embelezamento e medida sanitária, fortalecendo a ideia do jardim como auxílio no combate preventivo contra doenças.

90. João Dierberger atuou no ramo paisagístico no Brasil. Segundo Enokibara (2016, p. 35 ), ele fundou sua primeira empresa "voltada à produção e comercialização de plantas ornamentais, hortícolas e frutíferas, bem como à elaboração e execução de jardins em 1993 na cidade de São Paulo". A partir de 1919, Reynaldo Dierberger e João Dierberger Jr., filhos do patriarca João Dierberger e Elisa Trebitz, ingressaram na empresa, diversificando a expansão das atividades. O grupo Dierberger foi responsável por projetar e executar jardins de expressão, entre eles o do Palácio Guanabara (RJ), do Museu do Ipiranga (SP), a reforma dos jardins do Palácio dos Campos Elyseos (RJ), o parque e jardim da Ilha de Santa Theresa, de propriedade da família Guinle (RJ), a Praça da República de Jaboticabal e o Jardim Público de Poços de Caldas.

91. O velho cemitério (1913, p. 2).

92. Artese foi o responsável por cuidar do Jardim Artísti- 
co por mais de 40 anos, provendo-o dos cuidados com jardinagem, limpeza, energia, água e porteiro, custando-lhe parte dos seus bens em troca das dívidas acumuladas. De acordo com Del Guerra (2001), em 1957, após um acordo realizado entre a Prefeitura Municipal, Paschoal Artese e a Igreja (proprietária do terreno), o Jardim Artístico começou a ser demolido para ali serem construídos os prédios dos três poderes: Legislativo, Executivo e Judiciário.

93. Vicente Larocca nasceu em São Paulo no dia 2 de janeiro de 1892. Segundo Lourenço (2002, p. 270), Vicente foi aluno do Liceu de Artes e Ofícios do Rio de Janeiro, onde se especializou em escultura, se inclinando para a "retratística, sobretudo cabeças de crianças e projetos de grande porte". Foi também professor catedrático e diretor da Escola de Belas Artes de São Paulo. Larocca faleceu na capital paulista em 27 de julho de 1963.

94. Artese (1966, p. 9).

95. Os jardins públicos transformaram-se em espaços importantes dentro da malha urbana, lugar de ver e ser visto, ensejando um novo comportamento que, conforme as análises feitas por Ghirardello (2010) ao pesquisar a formação dos patrimônios religiosos no processo de expansão urbana do interior paulista, ocorria em consequência de um conjunto de fatores: repressão policial, intimação social e cultural. Desse modo, e como destacado por Ghirardello (2010, p. 206), a assepsia da paisagem se transferia "para aqueles que a usufruíam de acordo com os novos costumes, comportamentos e hábitos 'civilizados', nitidamente expressos com base em uma nova indumentária aos moldes europeus". O Jardim se estabeleceu como completo abandono: pasto para animais que eram tidos como assombrações. [...] Restos humanos foram transladados; melhoramos uma praça desaterrando-a [atual Praça Barão do Rio Branco] e conquistamos outra - a do cemitério - aterrando uma enorme grota que, além de inutilizá-la pela metade, interrompia o curso de uma rua vizinha [atual Rua Treze de Maio]; encomendamos estátuas no estrangeiro, e fontes ornamentais na Capital do Estado; contraímos também muitas dívidas que nos desorganizaram para sempre a vida econômica, somente com vistas à realidade desse sonho.

Durante mais de 40 anos conservamos às nossas expensas esse jardim com suas obras incompletas, hostilizadas pela política, depredadas por crianças e adultos; de sonho que era, nossa infeliz iniciativa converteu-se em atroz pesadelo. Longe de ser encontrado um acordo ou auxílio por parte das administrações que se sucederam, só tivemos delas uma guerra aberta, rancorosa. ${ }^{94}$

Preterido pelos políticos e por parte da população rio-pardense, o jardim, que não à toa era conhecido como Jardim do Artese, foi demolido em 1957, escancarando mais um conflito que extrapola a representação materialmente densa da atuação de Artese enquanto profissional da construção civil, atingindo o simbolismo de um agitador político, militante socialista, tido como ameaça ao poder local. Contudo, a destruição do jardim não apagou a influência significativa desse espaço no próprio modo de vida ${ }^{95}$ rio-pardense por mais de 40 anos, como mostram os relatos de Clara Alves Zenaro Garcia ${ }^{96}$ e Carmém Cecília Trovatto Maschietto ${ }^{97}$ e a descrição de Rodolpho José Del Guerra:

Ah era um jardim enorme. A gente ia para a escola e passava lá. Tinha uns pés de tamarindo, e ali foi o antigo cemitério, então a gente também tinha medo [risos]. Tinha bastante árvore frutífera, bancos e estátuas importadas. Chamava Jardim do Artese porque era o Artese quem cuidava. ${ }^{98}$

$\bigcirc$ jardim do Artese, eu me lembro perfeitamente. Tinha uma construção que a gente tinha medo de subir lá em cima, era o antigo cemitério, mas era uma delícia. A gente enforcava a aula e vinha aqui [Jardim Artístico], ficava namorando, tudo escondido. Durante a semana era mais estudante, fora sábado e domingo iam as pessoas passear, se divertir, comer. Tinha um pé de tamarindo e a gente ficava pegando, era azedinho. Tinha uma árvore que fazia borracha, que tem na Amazônia, a gente tirava, fazia bolinha e ficava que nem chiclete. $\bigcirc$ Jardim do Artese é uma lembrança inesquecível para todos da minha geração. ${ }^{99}$

$\bigcirc$ jardim teve sombras de tamarindeiro, de ficheiras, de figueiras... Teve esconderijos e emaranhadas trepadeiras... Teve recantos para brincar, papear, flautear, descansar, estudar, amar... Teve alerta jardineiro... Teve mirantes para mirar paisagens e devassos amores... Teve histórias intimidantes de cemitério, de ossos, de assombrações... Teve obras de arte legadas à municipalidade... ${ }^{100}$ 

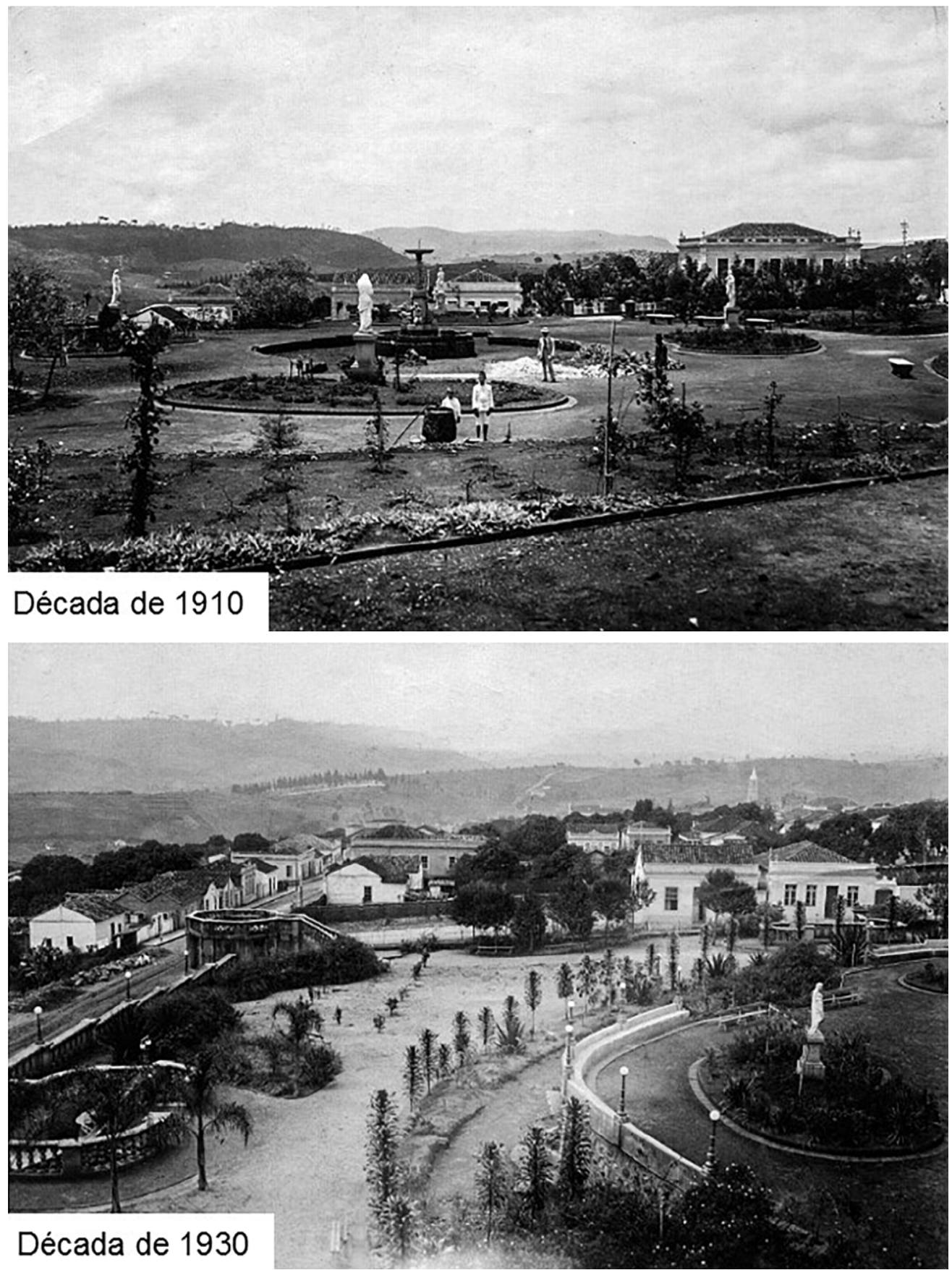

Figuras 10a e 10b - Jardim Artístico idealizado e mantido por Paschoal Artese. Fonte: Hemeroteca Jornalista Paschoal Artese. espaço pleno de domínio social, onde a natureza era controlada e atividades diversas eram realizadas, marcando o processo de laicização do espaço urbano.

96. Entrevista concedida a Natalia Cappellari de Rezende no dia 10 de setembro de 2016, em sua residência na Vila Pereira, São José do Rio Pardo.

97. Entrevista concedida a Natalia Cappellari de Rezende no dia 26 de setembro de 2016, em sua sala de direção na Universidade Paulista, Jardim Santa Tereza, São José do Rio Pardo.

98. Cf. Garcia (2016).

99. Cf. Maschietto (2016).

100. Del Guerra (2001, p. 295). 

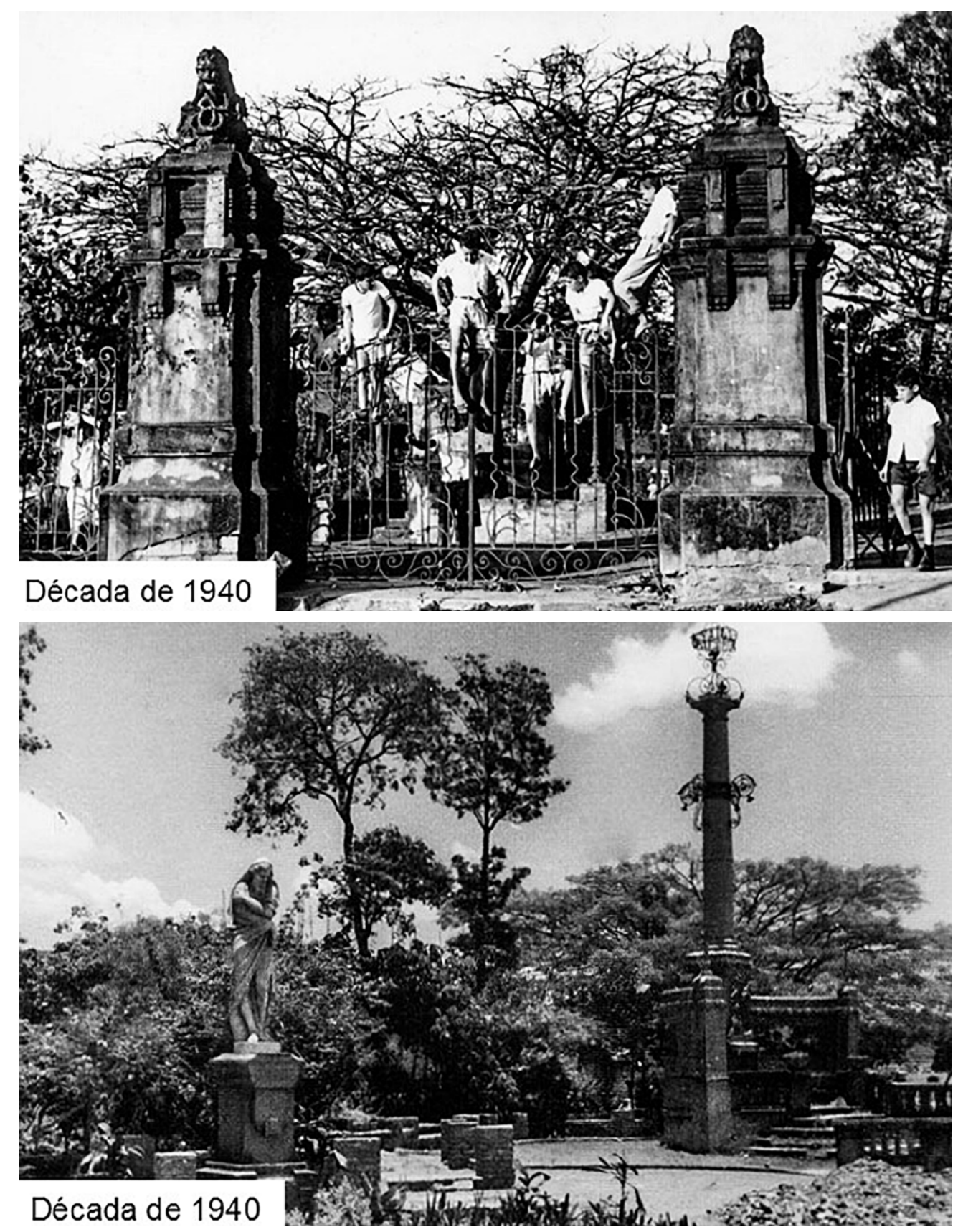

Figuras 10c e 10d - Jardim Artístico idealizado e mantido por Paschoal Artese. Fonte: Hemeroteca Jornalista Paschoal Artese. 
101. Artese se refere ao livro escrito por José Aleixo Irmão (1960), intitulado Euclides da Cunba e o socialismo. Aleixo Irmão residiu em São José do Rio Pardo em meados do século $\mathrm{XX}$, quando exerceu o cargo de promotor público. $\mathrm{O}$ propósito de sua obra era contradizer a atribuição de autoria de um programa socialista realizado por Euclides da Cunha em associação a outros militantes, como Paschoal Artese, em São José do Rio Pardo, entre os anos de 1898 e 1901.

102. Artese (1966, p. 9).

103. Ibid.

Não é preciso que thes contemos como foi a nossa campanha em favor do colono desprotegido - Aleixo Irmão fê-lo por nós num livro pago pelo Governo, editado e profusamente distribuído pela Casa de Euclides [atualmente Casa Euclidiana].

Toda fase de nossos primeiros anos aqui passados, ali está escrita e documentada, não para nos dignificar, mas, pelo contrário, para nos desmoralizar e eliminar uns tons vermeIhos que segundo ele, puséramos no retrato do grande escritor. Quiseram-no tão somente "verde e amarelo" e, para consegui-lo, tal como se faz com os criminosos, devassaram nossa vida pregressa a fim de nos apontar como mentirosos. ${ }^{102}$ 
Mas Artese teve o cuidado de esclarecer as circunstâncias em que se deu o trabalho realizado com ajuda de outros italianos e intelectuais, amigos de Euclides da Cunha, na defesa do trabalhador:

Voltamos a afirmar: foi com o auxílio dos amigos e intelectuais que rodeavam Euclides [Euclides da Cunha], que fundamos aqui, o Clube Filhos do Trabalho, ou "Filhos da Candinha", como foi alcunhado pelos nossos inimigos. Com tal medida procuramos congregar, amparar, defender o trabalhador, pleiteando-lhe as reivindicações para tirá-lo da condição de escravo em que se achava. ${ }^{103}$

Seu posicionamento político e social, externado também através dos jornais, combatendo políticos e fazendeiros, acabou colocando a sua vida em risco:

Foi nessa ocasião que surgiv o "O Proletário", órgão de ideias avançadas, defensor da classe operária, famoso pela sua missão corajosa. $\bigcirc$ bem proporcionado neste terreno, não só nos custaram difamações, processos, mas também por várias vezes, colocou nossa vida em perigo.

Datam dessa época o início das comemorações do $1^{\circ}$ de maio, ousadia que nos pôs na cadeia, naqueles tempos, em que uma alvorada com o Hino ao Trabalho, era coisa proibida, subversiva. ${ }^{104}$

Por fim, Artese encerra seu discurso dizendo que

Nada do que pretendemos construir, ficou de pé. Nosso esforço foi rejeitado naquilo que pretendêramos deixar ligado o nosso nome. Nossa obra, além de recusada, foi impiedosamente arrasada [...].

Enfim, de tudo quanto aqui nos aconteceu, de uma coisa estamos certos: o chão rio-pardense, nossa próxima morada, em que quase setenta anos caminhamos, agora, com pernas mal-firmes, tateando-o com uma bengala, nunca se riu, nem gozou de nossos fracassos, porque sabe do amor com que nele norteamos os nossos passos, induzido sempre pela melhor de nossas intenções. E, isto, nos consola! 105

Inegavelmente, Paschoal Artese foi um profissional que marcou presença em São José do Rio Pardo, mas as divergências de ideias e os conflitos gerados foram preponderantes a ponto de levar boa parte de suas obras à destruição. Levaram também a que ocorresse um apagamento intencional da memória e de sua atuação na cidade, mas não o suficiente para deslegitimar a sua inegável importância, ainda que se tratasse de um profissional não diplomado. É o caso, portanto, de uma "recusa deliberada" - usando os termos de Rita de Cássia Francisco - à ausência desse profissional virtuose na história escrita rio-pardense. Particularidades que também 
ajudam a explicar a sua ausência na historiografia da arquitetura e do urbanismo, por vezes ainda narrada sob a distinção elitista forjada na tríade Estado, universidade e diploma, com a qual Paschoal Artese não se coaduna. Diante disso, o desafio de inscrevê-lo na escrita da história necessariamente perpassa a perspectiva de identificação e análise de conflitos materiais e simbólicos para caracterizar sua atuação como profissional não diplomado da construção civil entre fins do século XIX e a década de 1910, em uma cidade do interior do estado de São Paulo. 


\section{REFERÊNCIAS}

FONTES IMPRESSAS

ARTESE, Paschoal. [Discurso à Câmara Municipal de São José do Rio Pardo, 30 de dezembro de 1966]. In: TREVISAN, Bene. Germinal Artese. São José do Rio Pardo, 1995.

AULA NOCTURNA para o ensino do desenho. O Rio Pardo, São José do Rio Pardo, ano II, $\mathrm{n}^{\mathrm{o}} 140$, p. 2, 26 jul. 1900.

FESTA DO MES DE MARIA E NOSSA SENHORA APARECIDA. O Rio Pardo, São José do Rio Pardo, ano XI, n 664, p. 4, 16 maio 1909.

NOVO PUlPITO. O Rio Pardo, São José do Rio Pardo, ano VI, nº 360, p. 1, 4 set. 1904.

O VElHO CEMITÉRIO. O Rio Pardo, São José do Rio Pardo, ano XIV, nº 840, p. 2, 1 fev. 1913.

SÃO JOSÉ DO RIO PARDO. Código de posturas de 1903. São José do Rio Pardo, 1903.

TREVISAN, Amélia Franzolin. Paschoal Artese, o urbanista e jornalista. Jornal Gazeta do Rio Pardo, São José do Rio Pardo, página 3a, 10 abr. 1977.

LIVROS, ARTIGOS E TESES

ARTIGAS, João Batista Vilanova. Caminhos da arquitetura. São Paulo: Fundação Vilanova Artigas, 1986.

ASENDORF, Christoph. Batteries of life: on the history of things and their perception in modernity. Berkeley: University of California Press, 1984.

BARBOSA, Ana Mae. Arte-educação no Brasil: das origens ao modernismo. São Paulo: Perspectiva, 1978. 
BELluZZO, Ana Maria de Moraes. Artesanato, arte e indústria. 1988. Tese (Doutorado em Arquitetura e Urbanismo) - Faculdade de Arquitetura e Urbanismo, Universidade de São Paulo, São Paulo, 1988.

BITTENCOURT, Gean Maria. A missão artística francesa de 1816. Rio de Janeiro: Museu de Armas Ferreira da Cunha, 1967.

BORTOLUCCI, Maria Angela Pereira de Castro e Silva. Moradias urbanas construídas em São Carlos no período cafeeiro. 1991. Tese (Doutorado em Arquitetura e Urbanismo) - Faculdade de Arquitetura e Urbanismo, Universidade de São Paulo, São Paulo, 1991.

BRUAND, Yves. Arquitetura contemporânea no Brasil. São Paulo: Perspectiva, 1981.

BRUNO, Ernani da Silva. História e tradições da cidade de São Paulo. São Paulo: Hucitec, 1984.

CAMARGO, Mônica Junqueira de. Novas fontes documentais no contexto da historiografia da arquitetura moderna. In: ENCONTRO DA ASSOCIAÇÃO NACIONAL DE PESQUISA E PÓS-GRADUAÇÃO EM ARQUITETURA E URBANISMO, 3., 2014, São Paulo. Anais [...]. São Paulo: Universidade Presbiteriana Mackenzie; Campinas: Pontifícia Universidade Católica de Campinas, 2014. p. 1-16.

CORREIA, Telma de Barros. A construção do habitat moderno no Brasil: 1870-1950. São Carlos: RiMa, 2004.

COSTA, Cacilda Teixeira da. O sonbo e a técnica: a arquitetura de ferro no Brasil. São Paulo: Edusp, 2001.

COSTA, Lúcio. Lúcio Costa: sôbre arquitetura. Porto Alegre: Centro dos Estudantes Universitários de Arquitetura, 1962.

COSTA, Lúcio. Razões da nova arquitetura. Revista da Diretoria de Engenharia da Prefeitura do Distrito Federal, Brasília, DF, v. 3, n. 1, p. 3-9, 1936.

COSTA, Lúcio. Registro de uma vivência. São Paulo: Empresa das Artes, 1995.

DEBENEDETTI, Emma; SALMONI, Anita. Arquitetura italiana em São Paulo. Sa?o Paulo: Perspectiva, 1981.

DE FELICE, Renzo. Sindacalismo rivoluzionario e fiumanesimo nel carteggio De AmbrisD’Annunzio. Brescia: Morcelliana, 1966. 
DEL GUERRA, Rodolpho José. A São José, una nuova storia. São Sebastião da Grama: Grass, 1999.

DEL GUERRA, Rodolpho José. E as sementes florescem... São José do Rio Pardo: Graf-Center, 2002.

DEL GUERRA, Rodolpho José. No ventre da terra mãe. São José do Rio Pardo: Graf-Center, 2001.

DURANT, Stuart. Ornament: a survey of decoration since 1830. London: Macdonald, 1986.

ENOKIBARA, Marta. Organizações Dierberger (1893-1940). Paisagem e Ambiente, São Paulo, n. 38, p. 35-54, 2016.

FABRIS, Annateresa. Arquitetura eclética no Brasil: o cenário da modernização. Anais do Museu Paulista, São Paulo, v. 1, n. 1, p. 131-146, 1993.

FABRIS, Annateresa (Org.). Ecletismo na arquitetura brasileira. São Paulo: Nobel, 1987.

FRANCISCO, Rita de Cássia. Construtores anônimos em Campinas (1892-1933): fortuna crítica de suas obras na historiografia e nas políticas de preservação da cidade. 2013. Tese (Doutorado em Arquitetura e Urbanismo) - Faculdade de Arquitetura e Urbanismo, Universidade de São Paulo, São Paulo, 2013.

FREYRE, Gilberto. Ingleses no Brasil: aspectos da influência britânica sobre a vida, a paisagem e a cultura do Brasil. Rio de Janeiro: José Olympio, 1948.

GHIRARDELLO, Nilson. A formação dos patrimônios religiosos no processo de expansão urbana paulista (1850/1900). São Paulo: Editora Unesp, 2010.

GOODWIN, Philip L.; SMITH, George Everard Kidder. Brazil builds: architecture new and old 1652-1942 / Construção brasileira: arquitetura moderna e antiga, 1652-1942. New York: Museum of Modern Art, 1943.

IRMÃO, José Aleixo. Euclides da Cunha e o socialismo. São José do Rio Pardo: Casa Euclidiana, 1960.

KÜHL, Beatriz Mugayar. Arquitetura do ferro e arquitetura ferroviária em São Paulo: reflexões sobre a sua preservação. São Paulo: Fapesp, 1998.

LEMOS, Carlos Alberto Cerqueira. Alvenaria burguesa: breve história da arquitetura residencial de tijolos em São Paulo a partir do ciclo econômico liderado pelo café. São Paulo: Nobel, 1989. 
LEMOS, Carlos Alberto Cerqueira. Ecletismo em São Paulo. In: FABRIS, Annateresa (Org.). Ecletismo na arquitetura brasileira. São Paulo: Nobel, 1987. p. 68-103.

LEMOS, Nathalia Gama. Um império nos trópicos: a atuação do Intendente Geral de Polícia, Paulo Fernandes Viana, no império luso-brasileiro (1808-1821). 2012. Dissertação (Mestrado em História) - Universidade Federal Fluminense, Niterói, 2012.

LEPETIT, Bernard. Arquitetura, geografia, história: usos da escala. In: LEPETIT, Bernard (Org.). Por uma nova história urbana. São Paulo: Edusp, 2001. p. 191-226.

LIMA, Roberto Pastana Teixeira. Modelos portugueses e arquitetura brasileira: catálogo e análise das formas arquiteturais paulistas e lusitanas no Oitocentos. Tese (Doutorado em História) - Instituto de Filosofia e Ciências Humanas, Departamento de História, Universidade de Campinas, Campinas, 2001.

LIMA, Solange Ferraz de. Ornamento e cidade: ferro, estuque e pintura mural em São Paulo, 1870-1930. 2001. Tese (Doutorado em História) - Faculdade de Filosofia Letras e Ciências Humanas, Universidade de São Paulo, São Paulo, 2001.

LIMA, Solange Ferraz de. O trânsito dos ornatos: modelos ornamentais da Europa para o Brasil, seus usos (e abusos?). Anais do Museu Paulista, São Paulo, v. 16, n. 1, p. 151-199, 2008.

LOURENÇO, Maria C. F. (Org.). Homenagem aos mestres: esculturas na USP. São Paulo: Editora da Universidade de São Paulo, 2002. (Cadernos CPC, 5).

MACAMBIRA, Yvoty de Macedo Pereira. Os italianos e a arquitetura paulistana. Revista de Italianística, São Paulo, ano 3, n. 3, p. 57-72, 1995.

MACAMBIRA, Yvoty de Macedo Pereira. Os mestres da fachada. São Paulo: Centro Cultural São Paulo, 1985.

MARINS, Paulo Cesar Garcez. Através da rótula: sociedade e arquitetura no Brasil, séculos XVII a XX. São Paulo: Humanitas, 2001.

MONTEIRO, Ana Maria Reis de Góes. Ramos de Azevedo: presença e atuação profissional em Campinas. Campinas: Unicamp, 2009.

NAYLOR, Gillian. The arts and crafts movement: a study of its sources, ideals, and influence on design theory. London: Studio Vista, 1971. 
MOTTA, Flávio Lichtenfels. Art nouveau: um estilo entre a flor e a máquina. Rio de Janeiro: Cadernos Brasileiros, 1965.

PARETO JÚNIOR, Lindener. O cotidiano em construção: os "práticos licenciados" em São Paulo (1893-1933). 2011. Dissertação (Mestrado em Arquitetura e Urbanismo) - Faculdade de Arquitetura e Urbanismo, Universidade de São Paulo, São Paulo, 2011.

PARETO JÚNIOR, Lindener. Pândegos, rábulas, gamelas: os construtores não-diplomados entre a engenharia e a arquitetura (1890-1960). 2016. Tese (Doutorado em Arquitetura e Urbanismo) - Faculdade de Arquitetura e Urbanismo, Universidade de São Paulo, São Paulo, 2016.

PINHEIRO, Maria Lucia Bressan. Neocolonial, modernismo e preservação do patrimônio no debate cultural dos anos 1920 no Brasil. São Paulo: Edusp, 2011.

PUPPI, Marcelo. Por uma história não moderna da arquitetura brasileira: questões de historiografia. Campinas: Associação dos Amigos da História da Arte, 1998.

RAMALHO, Maria Lucia Bressan. Da beaux-arts ao bungalow: uma amostragem da arquitetura eclética no Rio de Janeiro e em São Paulo. 1989. Dissertação (Mestrado em Arquitetura e Urbanismo) - Faculdade de Arquitetura e Urbanismo, Universidade de São Paulo, São Paulo, 1989.

REIS FILHO, Nestor Goulart. Quadro da arquitetura no Brasil. São Paulo: Perspectiva, 2011.

REZENDE, Natalia Cappellari. A cidade de São José do Rio Pardo e as moradias do Centro Histórico (1865-1940). 2019. Dissertação (Mestrado em Arquitetura e Urbanismo) - Instituto de Arquitetura e Urbanismo, Universidade de São Paulo, São Carlos, 2019.

RIBEIRO, Suzana Barretto. Inventário arquitetônico de Mococa. Campinas: Direção Cultura, 2011.

RYKWERT, Joseph. Lo clássico y lo neoclássico In: RYKWERT, Joseph. Los primeros modernos: los arquitectos del siglo XVIII. Barcelona: Gustavo Gili, 1982. p. 9-52

SALVADORE, Waldir. Italiano e nosso: Felisberto Ranzini e o "estilo florentino". São Paulo: Cultura Acadêmica, 2015.

SEGAWA, Hugo Massaki. Arquiteturas no Brasil, 1900-1990. São Paulo: Editora da Universidade de São Paulo, 2014.

SILVA, Antonio de Moraes. Diccionario da língua portugueza. Lisboa: Typographia de Joaquim Germano de Souza Neves, 1877. 
SILVA, Antonio Moraes. Diccionario da lingua portugueza. Lisboa: Typographia de Joaquim Germano de Souza Neves, 1878.

SILVA, Geraldo Gomes da. Arquitetura do ferro no Brasil. São Paulo: Nobel, 1986.

SILVERMAN, Debora. Art nouveau in fin-de-siècle France: politics, psychology and style. Los Angeles: University of California Press, 1989.

TOLEDO, Edilene Teresinha. O sindicalismo revolucionário em São Paulo e na Itália: circulação de ideias e experiências na militância sindical transnacional entre 1890 e o fascismo. Tese (Doutorado em História) - Instituto de Filosofia e Ciências Humanas, Universidade Estadual de Campinas, Campinas, SP, 2002.

TORRES, Mário H. G. A casa de Grandjean de Montigny na Gávea. In: PONTIFÍCIA UNIVERSIDADE CATÓLICA DO RIO DE JANEIRO (Org.). Uma cidade em questão I: Grandjean de Montigny e o Rio de Janeiro. Rio de Janeiro: PUC, 1979. p. 81-114.

TREVISAN, Bene. Germinal Artese: 1903-1982: vida \& obra. São José do Rio Pardo: Museu Rio-Pardense, 1995.

VERDELHO, Telmo. O dicionário de Morais Silva e o início da lexicografia moderna. In: HISTÓRIA DA LÍNGUA E HISTÓRIA DA GRAMÁTICA, 2003, Braga. Actas [...]. Braga: Universidade do Minho, 2003. p. 473-490.

ZVEIBIL, Vera Helena Bressan. Machado: retrato de família. São Paulo: V. H. B. Zveibil, 2000.

ENTREVISTAS

GARCIA, Clara Alves Zenaro. Entrevista concedida a Natalia Cappellari de Rezende. São José do Rio Pardo, 10 de setembro de 2016.

MASCHIETTO, Carmém Cecília Trovatto. Entrevista concedida a Natalia Cappellari de Rezende. São José do Rio Pardo, 26 de setembro de 2016.

Artigo apresentado em 14/1/2020. Aprovado em 1/7/2020 (cc) BY

All the contents of this journal, except where otherwise noted, is licensed under a Creative Commons Attribution Licens 